\title{
Electronic cigarettes and vaping: a new challenge in clinical medicine and public health. A literature review
}

\section{Dominic L. Palazzolo*}

Department of Physiology and Pharmacology, DeBusk College of Osteopathic Medicine, Lincoln Memorial University, Harrogate, TN, USA

\section{Edited by:}

SangNam Ahn, The University of Memphis School of Public Health, USA

\section{Reviewed by:}

Laura Rudkin, University of Texas Medical Branch, USA

Sandie Uyen Ha, University of Florida, USA

\section{*Correspondence:}

Dominic L. Palazzolo, Department of Physiology and Pharmacology, DeBusk College of Osteopathic Medicine, Lincoln Memorial University, 6965 Cumberland Gap

Parkway, Harrogate, TN 37752, USA e-mail:dominic.palazzolo@ Imunet.edu
Electronic cigarette (e-cigarette) use, or vaping, in the United States and worldwide is increasing. Their use is highly controversial from scientific, political, financial, psychological, and sociological ideologies. Given the controversial nature of e-cigarettes and vaping, how should medical care providers advise their patients? To effectively face this new challenge, health care professionals need to become more familiar with the existing literature concerning e-cigarettes and vaping, especially the scientific literature. Thus, the aim of this article is to present a review of the scientific evidence-based primary literature concerning electronic cigarettes and vaping. A search of the most current literature using the pubmed database dating back to 2008, and using electronic cigarette(s) or e-cigarette(s) as key words, yielded a total of 66 highly relevant articles. These articles primarily deal with (1) consumer-based surveys regarding personal views on vaping, (2) chemical analysis of e-cigarette cartridges, solutions, and mist, (3) nicotine content, delivery, and pharmacokinetics, and (4) clinical and physiological studies investigating the effects of acute vaping. When compared to the effects of smoking, the scant available literature suggests that vaping could be a "harm reduction" alternative to smoking and a possible means for smoking cessation, at least to the same degree as other Food and Drug Administration-approved nicotine replacement therapies. However, it is unclear if vaping e-cigarettes will reduce or increase nicotine addiction. It is obvious that more rigorous investigations of the acute and long-term health effects of vaping are required to establish the safety and efficacy of these devices; especially parallel experiments comparing the cardiopulmonary effects of vaping to smoking. Only then will the medical community be able to adequately meet the new challenge e-cigarettes and vaping present to clinical medicine and public health.

Keywords: electronic cigarettes, nicotine addiction, nicotine replacement, smoking cessation, vaping, harm reduction

\section{INTRODUCTION}

Use of electronic cigarettes (e-cigarettes), referred to as vaping, is a relatively new phenomenon that is quickly gaining the interest of many long-time tobacco smokers. According to a report by UBS Securities LLC (1), sales from the e-cigarette market doubled from $\$ 250$ to $\$ 500$ million between 2011 and 2012, and are expected to quadruple by 2014. E-cigarettes are becoming a preferred alternative for nicotine delivery among many smokers because of their realistic look, feel, and taste compared to traditional cigarettes. Furthermore, many cigarette smokers have turned to vaping because e-cigarette vendors have previously marketed their product as a cheaper and safer smokeless alternative to traditional cigarettes, and a possible smoking cessation tool. The Food and Drug Administration (FDA) rejected these claims, and in September of 2010 they informed the President of the Electronic Cigarette Association (2) that warning letters had been issued to five distributors of e-cigarettes for "violations of good manufacturing practices, making unsubstantiated drug claims, and using the devices as delivery mechanisms for active pharmaceutical ingredients." Many web sites still claim that use of e-cigarettes is safe because tobacco is not burned and hence there is no inhalation of the many toxins found in cigarette smoke. For example, Electronic Cigarette Consumer Reviews (3), an e-cigarette website, is filled with anecdotal consumer claims relating how e-cigarettes helped them to quit smoking and improved their overall health.

The FDA has reported that e-cigarette cartridges and solutions contain nitrosamines, diethylene glycol, and other contaminants potentially harmful to humans (4). From their analysis, the FDA reasons that the sale of e-cigarettes should be prohibited or regulated as dangerous nicotine delivery systems that comply with the safety standards of the Federal Food Drug and Cosmetic Act (FDCA) (5). This presents an obvious dilemma since traditional cigarettes, which include nicotine, are proven to be harmful to human health, but are exempt from the FDCA safety standards. After Smoking Everywhere, Inc., filed an injunction against the FDA for restricting the sale of their e-cigarettes in the United States (6), the US Court of Appeals (7) decided that e-cigarettes may not be marketed as a safer alternative to cigarettes, or as a smoking cessation device, but instead must be sold as a smokeless tobacco product subject to the same rules and regulations of other tobacco products. What makes this ruling so controversial is that e-cigarettes contain no tobacco other than a miniscule 
quantity found in the tobacco flavoring. Despite the court's decision, e-cigarette vendors have embraced this ruling, and are happy to sell their devices as alternatives to conventional cigarettes, so long as the FDA does not interfere with the sale of their products. Nevertheless, the potential harmful effects of vaping have led the FDA to issue Internet warnings regarding the risks of vaping (8). While the FDA has serious concerns regarding their use, Health New Zealand Ltd. (HNZ), a private enterprise which analyzed the safety of the Ruyan ${ }^{\circledR}$ e-cigarette with Ruyan ${ }^{\circledR}$ financial support, recommends the use of e-cigarettes as an alternative to traditional smoking (9). HNZ bases its recommendation on the likelihood that vaping is potentially less dangerous than traditional smoking; in other words, their message is "harm reduction." Cahn and Siegel (10) support HNZ's recommendation, concluding that "electronic cigarettes show tremendous promise in the fight against tobacco-related morbidity and mortality." In addition to reducing tobacco-related morbidity and mortality, vaping may also reduce harm incurred from second hand smoke and benefit the environment (11).

Foulds et al. $(12,13)$ believe that more research needs to be conducted to determine the safety and efficacy of e-cigarettes as a smoking cessation tool. However, they also state that individuals who have successfully quit smoking in favor of vaping should continue to use e-cigarettes as a healthier alternative to conventional cigarettes. Although there are clear perceptions among e-cigarette users that e-cigarettes can be used as both a smoking cessation tool, and a safer alternative to smoking, they can be marketed as neither. The FDCA (5) precludes their use as a smoking cessation tool, and the Family Smoking Prevention and Tobacco Control Act (14) precludes their use as a reduced-risk alternative; therefore, e-cigarettes must be sold as a tobacco product. E-cigarettes could play an important role in the future of smoking cessation, but their use is currently clouded by a tangle of legal and political issues. It is evident that more research on the safety and efficacy of e-cigarettes needs to be conducted, and that more stringent quality control measures should be implemented in order for the legal and political ramifications surrounding these products can be untangled.

The medical community must prepare itself to face the new challenge concerning e-cigarettes and vaping as a "harm reduction" tool. As a consequence of past lessons learned from "Big Tobacco" companies, the medical community is suspicious of ecigarettes and has routinely advised against their use (15). The medical community advises on the side of caution, indicating that very little scientific evidence is available to show, one way or the other, that e-cigarettes are safe to use, or that they help in the smoking cessation process. In addition, many physicians fear that patients who vape are merely substituting one form of nicotine addiction for another. While there are certainly potential perils associated with vaping, smoking, the leading cause of preventable disease in the United States, is likely to be more dangerous than vaping, especially when considering the myriad of known toxins found in cigarette smoke and the diseases which they promote. Assuming this premise is true, what should the primary medical focus be for a patient who has successfully transitioned from conventional cigarettes to e-cigarettes? Should it be to maintain smoking abstinence, or should it be to quit vaping? Would it not be prudent for a patient who is unwilling to quit smoking or give up nicotine to vape instead of smoke? Given these circumstances, how should patients be advised? The potential health hazards of nicotine addiction from smokeless tobacco products have previously been reviewed in a policy statement by the American Heart Association and include hemodynamic effects, endothelial dysfunction, thrombogenesis, systemic inflammation, and other metabolic effects (16). Understandably, the medical community (15) is concerned that increased availability of e-cigarettes could increase worldwide nicotine dependence, especially among the young as they are enticed by the various flavor options e-cigarettes have to offer. Since vaping does not produce smoke from burning tobacco, the opponents of e-cigarettes fear that traditional smokers will substitute vaping for smoking in settings where smoking is not permitted without any real intention of quitting conventional cigarettes. Furthermore, vaping in public places, coupled with recent e-cigarette commercials on national television, could possibly undermine or weaken current antismoking regulations. Health care professionals will need to consider and weigh what is more harmful to the public, continued smoking or increased nicotine addiction. As e-cigarettes gain greater popularity among smokers, these challenges will undoubtedly occur with increasing frequency.

In order to face this new challenge, health care professionals will need to become familiar with the available scientific evidencebased literature concerning e-cigarettes and vaping. Currently, this literature is sparse, but growing fast, and primarily deals with (1) consumer-based surveys regarding personal views on vaping, (2) chemical analysis of e-cigarette cartridges, solutions, and mist, (3) nicotine content, delivery, and pharmacokinetics, and (4) clinical and physiological studies investigating the acute effects of vaping. Only after reviewing the current literature can physicians and other health care providers give appropriate counsel regarding the role of e-cigarettes and vaping as a safer alternative to smoking, and as a smoking cessation tool (17). Consequently, the aim of this article is to provide a review of the current literature concerning e-cigarettes and vaping so that the medical community can better prepare for the new challenge these devices bring to clinical medicine and public health. The search for relevant scientific literature was accomplished using the pubmed database in which the key words electronic cigarette(s) or e-cigarette(s) were used. The search for articles extended back to 2008 and only highly relevant evidence-based primary literature was retrieved for review. Sixty-six articles dealing with surveys soliciting personal views on vaping; studies analyzing potential toxins and contaminants in ecigarette cartridges, solutions, and mist; reports profiling nicotine content, delivery, and pharmacokinetics; and clinical and physiological studies investigating the effects of acute vaping were ultimately used. Of these articles, two were published between 2008 and 2009. Six, ten, and fifteen articles were published in 2010, 2011, and 2012, respectively. Thus far, 33 highly relevant articles have been published in 2013, indicating a progressive increase in e-cigarette related research.

\section{CONSUMER-BASED SURVEYS}

Surveys have shown that awareness of e-cigarettes has quadrupled between 2009 and 2011 (18) and that they have a high adoption 
rate among traditional smokers $(19,20)$. Many current and exsmokers use e-cigarettes as a nicotine replacement therapy (NRT) to help them reduce or quit smoking $(13,21-25)$ while others use e-cigarettes as a less harmful alternative to smoking $(21,23,26,27)$. At the end of 6 months, Polosa et al. found that vaping e-cigarettes decreased consumption of conventional cigarettes by $80 \%$ after 6 months (28) and 50\% after 24 months (29). Caponnetto et al. reported similar reductions in cigarette consumption and cigarette abstinence after a year-long trial of using e-cigarettes in both normal smokers (30) and in chronic schizophrenic smokers (31). The authors claim that withdrawal symptoms were minimal and that the perception and acceptance of e-cigarettes was satisfactory, even in the schizophrenic patients. The results of Vickerman et al. (32) are less optimistic. They reported that nearly a third of 2758 callers to six state tobacco quit lines had ever used e-cigarettes of which $61.7 \%$ used the e-cigarettes for $<1$ month. Barbeau et al. (26) reported that using e-cigarettes, in comparison to other FDAapproved NRTs, such as nicotine gum, patches, and inhalers, had less annoying side effects and were more effective in preventing relapse, primarily because vaping retained the psychosocial aspects of real smoking better than the FDA-approved NRTs. Hua et al. (33) found a total of 405 different health-related effects (78 positive, 326 negative, and 1 neutral) reported by e-cigarette users in three different online forums. Users reporting negative health-related effects often reported multiple symptoms, while users reporting positive health-related effects usually reported a single symptom. Additionally, negative health-related effects occurred most frequently in the respiratory, neurological, sensory, and digestive systems while the positive health-related effects occurred solely in the respiratory system.

It is possible that the decreased daily consumption of conventional cigarettes among e-cigarette users, as seen in some studies (28-31), is at least partially due to a psychological element involving smokers' motivation to quit. Support for this idea is seen in a recent Hawaiian multiethnic study (34) involving 1567 traditional smokers of which $13 \%$ were also e-cigarette users attempting to quit smoking. This survey reported that smokers who used ecigarettes as a smoking cessation tool were more serious about wanting to quit smoking as compared to smokers who did not use e-cigarettes. In addition, e-cigarettes were also viewed as a viable option to other FDA-approved smoking cessation tools. Sutfin et al. (35) surveyed 4444 students from eight North Carolina colleges and found that 216 of these students had experimented with e-cigarettes (ever e-cigarette users) while 4228 had never used ecigarettes (never e-cigarette users). Of the ever e-cigarette users, $12 \%$ were never smokers, $30 \%$ were former or experimental smokers, 33\% were current non-daily smokers, and 9\% were current daily smokers compared to $53,19,14$, and $4 \%$, for the never e-cigarette users, respectively. When the ever e-cigarette users were asked about e-cigarette harm perception, $17 \%$ indicated ecigarettes are as harmful as conventional cigarettes, $45 \%$ responded with less harmful, 3\% thought e-cigarettes to be more harmful, and $23 \%$ were unsure. The never e-cigarette users responded with $16,22,2$, and $51 \%$, respectively. This data suggest that vaping is more common, but not exclusive, among traditional smokers. Another statistic revealed that vaping among young college students (mean age $20.7 \pm 2.9$ years) does not appear to be motivated by any intention to quit smoking. This is somewhat in contrast to Pokhrel et al. (34) who indicated more serious intentions toward smoking cessation among an older population of smokers using e-cigarettes (mean age $42.3 \pm 1.02$ years) compared to smokers not using e-cigarettes (mean age $45.63 \pm 0.35$ years). They also reported that individuals who took up vaping as a means to quit smoking were significantly younger and had smoked for less years than those who never vaped.

A concern of the FDA (8) and the medical community (15) is that availability of e-cigarettes will entice teens and young adults toward vaping, which could ultimately lead to smoking conventional cigarettes. Currently, there is little or no concrete evidence confirming the validity of this concern. Cho et al. (36) used data collected from a Korean Health Project to determine awareness and use of e-cigarettes. They found that $10.2 \%$ of 4353 students were aware of e-cigarettes, but only $0.5 \%$ of those students had actually tried e-cigarettes. Pepper et al. (37) conducted a national online survey of 228 male adolescents (ages 11-19) and determined that $<1 \%$ of these individuals actually tried e-cigarettes. On the other hand, $67 \%$ of the respondents were aware of e-cigarettes with awareness being higher among the older boys. Of those individuals who never tried e-cigarettes, $18 \%$ were willing to experiment with no preference toward flavored versus unflavored e-cigarettes. Additionally, smokers were more amiable to experiment with ecigarettes than non-smokers. In contrast, discussions with 11 focus groups involving 66 young adults (ages 18-26) revealed that young adults favorably perceive e-cigarettes and other new tobacco products specifically because they come in different flavors and that eliminating these flavors may reduce intentions to try these products (38). Another study surveyed 2624 US Midwestern young adults (ages 20-28) and indicated that $69.9 \%$ of the respondents were aware of e-cigarettes, but that only $7 \%$ actually tried vaping (39). Goniewicz et al. (40) conducted a survey of students enrolled at 176 nationally representative Polish high schools (ages 15-19) and universities (ages 20-24) and reported that 23.5\% of high school students and 19\% of university students had ever tried e-cigarettes. Of all the students who tried e-cigarettes, only $3.2 \%$ were non-smokers, which compares closely to the $4.9 \%$ reported by Sutfin et al. (35). Other strong correlates of e-cigarette use among adolescents include male gender, and having parents who smoke $(36,40)$. While a small percentage of young non-smokers experiment with e-cigarettes, it is more likely that young smokers will experiment with e-cigarettes. One fact emerges from these studies; as e-cigarette popularity increases, so does awareness of them among young individuals. How increasing awareness will ultimately affect e-cigarette usage by adolescent and young adults remains to be seen.

A number of studies (41-43) indicate that all forms of NRT are at least initially successful in maintaining cigarette abstinence. However, the successful long-term smoking cessation rate still remains relatively low. Employing a meta-analysis study, Hughes et al. (41) found the 6-month smoking quit rates for NRTs to be between 1 and $11 \%$ in seven studies as compared to between 3 and $5 \%$ in smokers who tried to quit on their own (44). Rennard et al. (42) reported a quit rate of $8 \%$ among smokers who used the nicotine inhaler for 15 months. In contrast, few studies have tested e-cigarettes as a smoking cessation tool $(28,29,45)$. From 
an online survey, Siegal et al. (45) reported that $31 \%$ (69 of 216) of the respondents were no longer smoking cigarettes after 6 months of using e-cigarettes. Of those respondents who quit smoking, $57 \%$ were still using e-cigarettes, $9 \%$ were using other tobacco free nicotine products, and $34 \%$ were completely nicotine free. Polosa et al. (28) investigated the effect of e-cigarettes on smoking cessation and discovered that $22.5 \%$ (9 of 40 ) of the participants had not had a cigarette in 6 months. Of that cohort, $67 \%$ were still using e-cigarettes while $33 \%$ were nicotine free. Similar results were reported in a 24-month study by Polosa et al. (29). These studies and others $(46,47)$ suggest that e-cigarettes could play a role in smoking reduction and cessation, and as a result could reduce the harm incurred by smoking as effectively as any FDAapproved NRT. However, the role of e-cigarettes on total nicotine abstinence is still highly questionable, and it has been suggested that one form of nicotine addiction is simply replacing another (26). A summary of the studies involving consumer-based surveys regarding personal views of vaping are shown in Table 1.

\section{CHEMICAL ANALYSIS OF E-CIGARETTE CARTRIDGES, SOLUTIONS, AND MIST}

The ingredients found in e-cigarette cartridges and solutions are relatively few, and for the most part non-toxic and noncarcinogenic, especially in the low quantities delivered. They include nicotine, propylene glycol, glycerin, and tobacco flavoring $(4,48)$. Propylene glycol, an FDA-approved solvent used in foods, a vehicle for intravenous diazepam, and as the major ingredient found in e-cigarette fluids, makes up about $90 \%$ of the solution (9). Certain contaminates, most of which are derived from tobacco flavoring, have been detected in e-cigarettes. A small amount of diethylene glycol (approximately 1\%), a known carcinogen and an ingredient in anti-freeze, was also detected in one out of 18 cartridges analyzed by the FDA (4). The source of the diethylene glycol contamination is not clear but could reflect the use of non-pharmaceutical grade propylene glycol (10). In comparison, cigarette smoke from burned tobacco products contains thousands of compounds, many of which have been shown to induce or promote carcinogenesis (49); specifically the trace metals (i.e., cadmium, arsenic, chromium, nickel, and lead), the tobacco specific N-nitrosamines (TSNA), the polycyclic aromatic hydrocarbons (PAHs), and the volatile organic compounds (VOCs). While investigations have shown some of these hazardous compounds to be present in e-cigarette cartridges, solutions, and mist, there are only a few reports detecting levels of these contaminates high enough to be of significant risk to humans. The HNZ study (9) found levels of arsenic cadmium, chromium, nickel, and lead to be undetectable in e-cigarette cartridge liquid. In contrast, Williams at al. (50) found levels of lead, chromium, and nickel in e-cigarette aerosol to be equivalent to, and in some cases higher than, what has been reported for cigarette smoke. They indicate that the primary source of these trace metals are the filaments inside the e-cigarette cartomizer (i.e., the aerosolizing component of the e-cigarette), and conclude that improved quality control of e-cigarette design and manufacturing would greatly reduce the presence of these trace metals. The FDA (4) and HNZ (9) both reported that e-cigarettes contain trace amounts of TSNAs, but the levels found in the e-cigarettes represent only a very small fraction $(0.008 \mu \mathrm{g} / \mathrm{e}$-cigarette cartridge containing $16 \mathrm{mg}$ of nicotine) of what is typically found in traditional cigarettes $(6.3 \mu \mathrm{g} / \mathrm{full}$ flavor Marlboro cigarette) (51). To put this into perspective, an ecigarette cartridge is good for about 150-300 puffs while a single conventional cigarette is good for about 10-15 puffs (52). The amount of total TSNAs found in other FDA-approved nicotine products was roughly equivalent to the total amount of TSNAs found in e-cigarettes $(9,10)$. Other studies $(11,53-56)$ confirm the low levels of TSNAs present in e-cigarette solutions and vapor, as well as the low or undetectable levels of particulate matter, trace metals, VOCs, and PAHs, especially when compared to the amounts present in cigarette smoke.

As previously mentioned (2), the FDA issued warnings to several e-cigarette companies for selling e-cartridges and refill solutions containing active pharmaceutical ingredients such as rimonabant (Zimulti ${ }^{\circledR}$ ) for the purpose of losing weight and reducing smoking addiction, and tadalafil (the active ingredient in Cialis $\left.{ }^{\circledR}\right)$ for the purpose of increasing sexual capacity. FDA analyses of these e-cartridges and solutions revealed the presence of aminotadalafil and not tadalafil, and the presence of an oxidative product of rimonabant, as well as rimonabant (57), although the amount of either of these substances that is able to transfer from liquid to vapor phase is low (58). Table 2 summarizes the studies involving chemical analyses of e-cigarette cartridges, solutions, and mist.

\section{NICOTINE CONTENT, DELIVERY, AND PHARMACOKINETICS}

E-cigarettes are designed to deliver nicotine in an aerosolized manner that simulates an authentic smoking experience without the real smoke. In this respect, e-cigarettes are similar to the FDA-approved nicotine inhaler. Bullen et al. (59) determined the Ruyan ${ }^{\circledR}$ e-cigarette had a nicotine pharmacokinetic profile very similar to the Nicotrol ${ }^{\circledR}$ inhaler, but the study's participants thought the e-cigarettes were more pleasant to use and produced less irritation to the mouth and throat. For e-cigarettes, the nicotine is delivered through cartridges prefilled with a nicotine solution or cartridges that the user fills with a nicotine refill solution. In either case, the nicotine concentration of the solutions or cartridges can be purchased in strengths ranging from 0 to $24 \mathrm{mg}$ or more, according to user preference. Unfortunately, the amounts of nicotine specified on the labels of various brands of e-cartridges and solutions have not always been accurate or consistent (60). The FDA $(4,57,58)$ confirmed the ability of e-cigarettes to deliver nicotine, but stated there is too much variability in the amount of nicotine delivered per puff of any e-cigarette cartridge for them to be considered safe. Repeated analysis of a menthol high strength Njoy ${ }^{\circledR}$ e-cigarette cartridge (18 mg of nicotine) yielded nicotine deliveries of $26.8,34.9$, and $43.2 \mu \mathrm{g} / 100 \mathrm{ml}$ puff. The medium strength Smoking Everywhere ${ }^{\circledR}$ e-cigarette cartridge $(11 \mathrm{mg}$ of nicotine) and the medium strength $\mathrm{Njoy}^{\circledR}$ e-cigarette cartridge (12 $\mathrm{mg}$ of nicotine) delivered 15.7 and $10.6 \mu \mathrm{g}$ nicotine $/ 100 \mathrm{ml}$ puff, respectively, and were found to be similar to the $10-\mathrm{mg}$ Nicotrol ${ }^{\circledR}$ inhaler shown to deliver $15.2 \mu \mathrm{g}$ nicotine $/ 100 \mathrm{ml}$ puff. Of major concern is that some e-cartridges and solutions that were labeled as containing $0 \mathrm{mg}$ of nicotine did in fact contain some nicotine $(4,57)$. The $\operatorname{FDA}(4,58)$ also detected small quantities of cotinine, a metabolite of nicotine, and several nicotine related impurities to include, anabasine, anatabine, myosmine, and 
Table 1 | Studies involving consumer-based surveys regarding personal views on vaping.

Authors (Reference) Study design

\begin{tabular}{ll}
\hline STUDIES REPORTING POSITIVE OR NEUTRA \\
Etter (21) & $\begin{array}{l}\text { Online French survey } \\
\text { at www.StopTabac.ch }\end{array}$ \\
& \\
Cho et al. (36) & $\begin{array}{l}\text { Survey of adolescents } \\
\text { from five schools } \\
\text { participating in a } 2008 \\
\text { Health Promotion } \\
\text { Fund Project }\end{array}$
\end{tabular}

Etter and Bullen (22)

Foulds et al. (12)

Polosa et al. (28)

Siegal et al. (45)

Goniewicz and

Zielinska-Danch

(40)

Kralikova et al. (19)

Interview of people

buying cigarettes

between 10 and 19

October 2011

purchased

Survey of students enrolled in at 176

nationally

representative high

schools and

universities in Poland

Participants

Participant's location

Key finding

81 Respondents, ages

19-65, 77\% male, 63\%

former smokers, $23 \%$ daily

smokers, $13 \%$ occasional

smokers

4353 Adolescent students Korea

$81 \%$ France

$8 \%$ Belgium

6\% Canada

5\% Switzerland

3587 Respondents, ages

31-52, 63\% male, 70\%

former smokers, $19 \%$ daily

smokers, $11 \%$ occasional

smokers

104 Respondents, mean age $34 \pm 9,74 \%$ male,

88\% Caucasian, 78\%

former smokers, 19\% daily smokers

40 Subjects (26 males) began and 27 subjects (18 males) ended 6 months later

Mean age $43 \pm 9$ years

Years smoked $27 \pm 9$ years

216 Respondents (72\%

male), ages 18-65+ years,

smokers for 5-30+ years

\section{0,240 High school}

students (15-19 years) and

university students

(20-24 years) $43 \%$ of

students were male

973 Respondents, average

age 32 years, and $54 \%$

male
$62 \%$ United States

14\% France

6\% United Kingdom

4\% Switzerland

3\% Canada

Philly Vapefest, 2011,

Philadelphia, PA

Recruited from the local

hospital staff in Catania, Italy

Worldwide. E-mail addresses were provided for 5000 first time online e-cigarette purchasers from the Blue-cigarette distributor and served as the pool of respondents

Poland

Five locations across Prague,

Czech Republic
E-cigarettes were used to quit

smoking

444 adolescent students had heard of e-cigarettes. 22 adolescents had ever tried e-cigarettes. Significant predictors of e-cigarette use include male gender and cigarette smoking experience

E-cigarette users believe that e-cigarettes helped them to quit or reduce smoking, and that vaping is less toxic than smoking

E-cigarette users believe that e-cigarettes helped them to quit smoking, and vaping is less harmful than smoking

Vaping e-cigarettes decreased consumption of traditional cigarettes as verified by exhaled carbon monoxide

After 6 months of vaping, 31\% of respondents were no longer smoking cigarettes

About $20 \%$ of polish youth have tried e-cigarettes, but only $3 \%$ of never smokers tried e-cigarettes. Not clear if e-cigarettes are a novelty that young people try once. Significant predictors of e-cigarette use include male gender and cigarette smoking experience

$86 \%$ of respondents have heard of e-cigarettes 
Table 1 | Continued

\begin{tabular}{|c|c|c|c|c|}
\hline Authors (Reference) & Study design & Participants & Participant's location & Key finding \\
\hline Barbeau et al. (26) & $\begin{array}{l}\text { Focus group } \\
\text { discussions posing } \\
\text { open ended questions }\end{array}$ & $\begin{array}{l}\text { Nine Men and two } \\
\text { women, ages } 18-64 \text { years }\end{array}$ & $\begin{array}{l}\text { Boston University School of } \\
\text { Public Health, Boston, MA, } \\
\text { USA }\end{array}$ & $\begin{array}{l}\text { Vaping was more effective in } \\
\text { maintaining cigarette abstinence } \\
\text { than the FDA-approved nicotine } \\
\text { replacement therapies due to } \\
\text { retention of behavioral and social } \\
\text { components of smoking addiction }\end{array}$ \\
\hline $\begin{array}{l}\text { Caponnetto et al. } \\
\text { (30) }\end{array}$ & $\begin{array}{l}\text { Regular smokers } \\
\text { recruited between } \\
\text { June } 2010 \text { and } \\
\text { February } 2011 \text { were } \\
\text { observed for } \\
12 \text { months }\end{array}$ & $\begin{array}{l}300 \text { Participants, mean age } \\
44 \pm 13 \text { years, } 63 \% \text { male } \\
\text { and smoke at least } 15-25 \\
\text { cigarettes/day }\end{array}$ & Catania, Italy & $\begin{array}{l}\text { The use of e-cigarettes, with or } \\
\text { without nicotine, decreased } \\
\text { cigarette consumption and elicited } \\
\text { tobacco abstinence as verified by } \\
\text { exhaled carbon monoxide }\end{array}$ \\
\hline $\begin{array}{l}\text { Caponnetto et al. } \\
\text { (31) }\end{array}$ & $\begin{array}{l}\text { Chronic schizophrenic } \\
\text { patients were } \\
\text { observed and } \\
\text { surveyed for } \\
12 \text { months }\end{array}$ & $\begin{array}{l}14 \text { Schizophrenic patients } \\
(6 \text { male), mean age } \\
45 \pm 13 \text { years and smoked } \\
\text { at least } 20-35 \\
\text { cigarettes/day }\end{array}$ & $\begin{array}{l}\text { CTA, Villa Chiara-Psichiatrica } \\
\text { Riabilitativa e Ricerca, } \\
\text { Catania, Italy }\end{array}$ & $\begin{array}{l}\text { The use of e-cigarettes decreased } \\
\text { e-cigarette consumption without } \\
\text { causing significant side effects in } \\
\text { schizophrenic patients }\end{array}$ \\
\hline Dawkins et al. (23) & $\begin{array}{l}\text { Online survey hosted } \\
\text { by the University of } \\
\text { East London with links } \\
\text { from TECC/TWEL } \\
\text { websites }\end{array}$ & $\begin{array}{l}1347 \text { Respondents, mean } \\
\text { age } 43 \text { years, } 70 \% \text { male } \\
\text { and } 96 \% \text { Caucasian }\end{array}$ & $\begin{array}{l}\text { Respondents from } 33 \\
\text { countries (72\% European) }\end{array}$ & $\begin{array}{l}\text { E-cigarettes are primarily used for } \\
\text { smoking cessation, but for a longer } \\
\text { duration than nicotine replacement } \\
\text { therapies }\end{array}$ \\
\hline Dockrell et al. (24) & $\begin{array}{l}\text { Three online surveys } \\
\text { and one focus group. } \\
\text { Respondents were } \\
\text { recruited from panel } \\
\text { of adults in Britains }\end{array}$ & $\begin{array}{l}\text { February } 2010 \text { online } \\
\text { population survey } \\
\text { ( } n=12,597 \text { for all } \\
\text { respondents with } n=2297 \\
\text { for smokers). April } 2010 \\
\text { online smokers' survey } \\
\text { ( } n=1380 \text { ). February } 2012 \\
\text { online population survey } \\
\text { ( } n=12,432 \text { for all } \\
\text { respondents with } n=2093 \\
\text { for smokers). March } 2010 \\
\text { focus group consisting of } \\
\text { smokers ( } n=37 \text { ) }\end{array}$ & Great Britain & $\begin{array}{l}\text { E-cigarette use may bridge the } \\
\text { smoking cessation process. There is } \\
\text { little evidence to suggest that } \\
\text { e-cigarettes is widely used among } \\
\text { never smokers }\end{array}$ \\
\hline
\end{tabular}


Table 1 | Continued

\begin{tabular}{|c|c|c|c|c|}
\hline Authors (Reference) & Study design & Participants & Participant's location & Key finding \\
\hline $\begin{array}{l}\text { Farsalinos et al. } \\
\text { (25) }\end{array}$ & $\begin{array}{l}\text { Recruitment and } \\
\text { survey of subjects } \\
\text { who had completely } \\
\text { substituted } \\
\text { conventional } \\
\text { cigarettes with } \\
\text { e-cigarettes for at } \\
\text { least } 1 \text { month }\end{array}$ & $\begin{array}{l}111 \text { Participants, } 84 \% \\
\text { male, mean age } \\
37 \pm 6 \text { years, that smoked } \\
\text { at least } 20-30 \text {, } \\
\text { cigarettes/day. Participants } \\
\text { had a mean smoking } \\
\text { duration of } 37 \pm 6 \text { years } \\
\text { and a smoking cessation } \\
\text { duration of } 4-11 \text { months }\end{array}$ & $\begin{array}{l}\text { Visitors to a Hospital in } \\
\text { Kallithea, Greece and to an } \\
\text { electronic cigarette } \\
\text { consumers' internet forum in } \\
\text { Greece }\end{array}$ & $\begin{array}{l}\text { E-cigarettes with higher nicotine } \\
\text { content were more successful in } \\
\text { the smoking cessation process }\end{array}$ \\
\hline $\begin{array}{l}\text { Goniewicz et al. } \\
\text { (27) }\end{array}$ & $\begin{array}{l}\text { Web-based survey of } \\
\text { e-cigarette users }\end{array}$ & 179 Respondents & Poland & $\begin{array}{l}\text { Participants primarily used } \\
\text { e-cigarettes to cease smoking and } \\
\text { reduce smoking related harm }\end{array}$ \\
\hline Li et al. (47) & $\begin{array}{l}\text { Telephone-based } \\
\text { survey by random } \\
\text { digit dialing of the } \\
\text { New Zealand Smoking } \\
\text { Monitor to recruit } \\
\text { current smokers and } \\
\text { recent quitters }\end{array}$ & $\begin{array}{l}840 \text { Current smokers and } \\
\text { recent quitters }\end{array}$ & New Zealand & $\begin{array}{l}\text { Only } 7 \% \text { of respondents ever } \\
\text { purchased e-cigarettes, } 33 \% \\
\text { perceived e-cigarettes as less } \\
\text { harmful than conventional } \\
\text { cigarettes and } 41 \% \text { believed } \\
\text { e-cigarettes are an acceptable } \\
\text { means to smoking cessation }\end{array}$ \\
\hline Pepper et al. (37) & $\begin{array}{l}\text { Online national survey } \\
\text { of male adolescents in } \\
\text { November } 2011 . \\
\text { Participants recruited } \\
\text { through parents who } \\
\text { were members of a } \\
\text { panel of U.S. } \\
\text { households }\end{array}$ & $\begin{array}{l}228 \text { Male adolescents, } \\
\text { ages } 11-19 \text { years }\end{array}$ & United States & $\begin{array}{l}\text { Only } 2 \text { of } 228 \text { adolescents had ever } \\
\text { tried e-cigarettes. } 18 \% \text { of adolescent } \\
\text { who were aware of e-cigarettes } \\
\text { were also willing to try them with } \\
\text { no preference to plain or flavored }\end{array}$ \\
\hline Pokhrel et al. (34) & $\begin{array}{l}\text { Cross-sectional survey } \\
\text { of Hawaiian Islanders } \\
\text { recruited through } \\
\text { newspaper } \\
\text { advertisement from } \\
2010 \text { to } 2012\end{array}$ & $\begin{array}{l}1567 \text { Participants divided } \\
\text { into two groups. Ever } \\
\text {-e-cigarette users ( } n=202 \\
\text { students; mean age } \\
42 \pm 1 \text { years, } 46 \% \text { male) } \\
\text { and never e-cigarette users } \\
\text { ( } n=1365 ; \text { mean age } \\
46 \pm 0.4 \text { years, } 51 \% \text { male) }\end{array}$ & Hawaiian Islands & $\begin{array}{l}\text { Smokers who try e-cigarettes } \\
\text { appear to be more serious about } \\
\text { smoking cessation and treat } \\
\text { e-cigarettes as valid alternatives to } \\
\text { FDA-approved nicotine replacement } \\
\text { therapies }\end{array}$ \\
\hline Polosa et al. (29) & $\begin{array}{l}\text { Tracking daily } \\
\text { consumption of } \\
\text { cigarettes for } \\
24 \text { months }\end{array}$ & $\begin{array}{l}\text { Follow-up observational } \\
\text { study of Polosa et al. (28). } \\
\text { See above }\end{array}$ & $\begin{array}{l}\text { Recruited from the local } \\
\text { hospital staff in Catania, Italy }\end{array}$ & $\begin{array}{l}\text { Long-term e-cigarette use can } \\
\text { substantially decrease conventional } \\
\text { cigarette consumption as verified by } \\
\text { exhaled carbon monoxide }\end{array}$ \\
\hline Regan et al. (18) & $\begin{array}{l}\text { Consumer-based } \\
\text { mail-in survey }\end{array}$ & $\begin{array}{l}10587 \text { Adult (18years or } \\
\text { older) respondents in } 2009 \\
\text { and } 10328 \text { adult ( } 18 \text { years } \\
\text { or older) respondents in } \\
2010\end{array}$ & United States & $\begin{array}{l}\text { Awareness of e-cigarettes doubled } \\
\text { from } 16 \% \text { in } 2009 \text { to } 32 \% \text { in } 2010\end{array}$ \\
\hline
\end{tabular}


Table 1 | Continued

\begin{tabular}{|c|c|c|c|c|}
\hline Authors (Reference) & Study design & Participants & Participant's location & Key finding \\
\hline Sutfin et al. (35) & $\begin{array}{l}\text { Web-based survey in } \\
\text { fall of } 2009\end{array}$ & $\begin{array}{l}4444 \text { Students divided into } \\
\text { two groups. Ever } \\
\text { e-cigarette users ( } n=216 \\
\text { students; mean age } \\
21 \pm 3 \text { years, } 53 \% \text { male) } \\
\text { and never e-cigarette users } \\
\text { ( } n=4228 ; \text { mean age } \\
21 \pm 3 \text { years, } 36 \% \text { male) }\end{array}$ & $\begin{array}{l}\text { Students from eight North } \\
\text { Carolina colleges }\end{array}$ & $\begin{array}{l}\text { E-cigarette use is more common } \\
\text { among smokers but not exclusive to } \\
\text { them. E-cigarette use among } \\
\text { college students does not appear to } \\
\text { be motivated by intentions to quit }\end{array}$ \\
\hline $\begin{array}{l}\text { Vickerman et al. } \\
\text { (32) }\end{array}$ & $\begin{array}{l}\text { Survey of callers to six } \\
\text { state tobacco quit } \\
\text { lines } 7 \text { months after } \\
\text { initially receiving } \\
\text { intervention }\end{array}$ & 2758 callers & $\begin{array}{l}\text { United States } \\
\text { The actual states were not } \\
\text { indicated }\end{array}$ & $\begin{array}{l}\text { Only about one third of the } \\
\text { respondents had ever tried } \\
\text { e-cigarettes of which } 62 \% \text { used for } \\
<1 \text { month }\end{array}$ \\
\hline \multicolumn{5}{|c|}{ STUDIES REPORTING NEGATIVE IMPACT OF E-CIGARETTES, VAPING, OR HARM REDUCTION } \\
\hline Choi et al. (38) & $\begin{array}{l}\text { Eleven focus group } \\
\text { discussions }\end{array}$ & $\begin{array}{l}66 \text { young adults, ages } \\
18-26 \text { years old }\end{array}$ & $\begin{array}{l}\text { University of Minnesota, } \\
\text { Minneapolis, Minnesota }\end{array}$ & $\begin{array}{l}\text { Young adults perceive e-cigarettes } \\
\text { and other new tobacco products } \\
\text { positively, especially when they are } \\
\text { flavored }\end{array}$ \\
\hline Hua et al. (33) & $\begin{array}{l}\text { Data collected from } \\
\text { postings of three high } \\
\text { traffic online forums }\end{array}$ & $\begin{array}{l}\text { Total of } 632 \text { posts from } \\
560 \text { different posters }\end{array}$ & $\begin{array}{l}\text { Worldwide but mostly from } \\
\text { the United States and Canada }\end{array}$ & $\begin{array}{l}\text { A total of } 405 \text { different, mostly } \\
\text { negative health-related effects, } \\
\text { were reported by e-cigarette users }\end{array}$ \\
\hline
\end{tabular}

$\beta$-nicotyrine in some, but not all, e-cartridge solutions and mist samples analyzed. Flouris and Oikonomou (61) question the rigor by which the FDA conducted these analyses, indicating that these analyses "cannot be used to draw conclusions or inferences about potential effects on health" until more rigorous chemical analyses, followed by extensive animal and clinical trials in humans, are conducted. Two other studies have also found discrepancies in the labeled nicotine content compared to the actual nicotine content in a number of e-cigarette brands $(52,62)$. Goniewicz et al. (52) reported relative percent differences between the labeled and actual nicotine concentration per cartridges (or refill fluids) to range between -89 and $28 \%$ in 30 popular brands of e-cigarettes. Cameron et al. (62) found the actual nicotine concentration in ecigarette cartridges and refill fluids to range from 1.8 to $23.7 \mathrm{mg} / \mathrm{ml}$ less than the labeled nicotine concentration. However, a more recent study analyzing several brands of e-cigarette refill solutions did find nicotine content to be accurate and consistent to what was printed on the label (63). Inconsistencies reported in nicotine concentrations, and hence deliveries, could be a reason why some e-cigarette users and not others report adverse reactions such as mouth and throat irritation, vertigo, headache, and nausea $(21,26,33)$. Incidentally, some of these same adverse reactions have also been reported for various FDA-approved NRTs (64). In a study evaluating design features, accuracy and clarity of labeling, and quality of printed materials and instruction manuals for e-cigarettes it was concluded that design flaws, inadequate product labeling, and lack of quality control in the manufacturing of e-cigarettes are an indication that stricter oversight and regulation are required for these devices (65). Accurate production, safe packaging, and proper storage of e-cigarette refill solutions are critical. Typically, a 5-ml vial of e-cigarette refill solution could contain a nicotine concentration of $20 \mathrm{mg} / \mathrm{ml}$ or $100 \mathrm{mg} / \mathrm{vial}$, and the known lethal dose of nicotine has been estimated to be about $10 \mathrm{mg}$ in children and between 30 and $60 \mathrm{mg}$ in adults (62). Given the potential health hazards of nicotine (16), inadvertent skin contact, or consumption of just one of these vials by children or pets could have tragic consequences. It is important that extreme caution be used when storing nicotine solutions.

Regardless of the inaccuracies and inconsistencies in the production of e-cigarette cartridges and solutions, puff-for-puff, the amount of nicotine finding its way into the blood stream from vaping an e-cigarette has been shown to be less than what you would expect from smoking a conventional cigarette with comparable nicotine content $(59,66,67)$. These studies report little or no increases in blood nicotine levels of naive subjects after acute predefined use of e-cigarettes compared to conventional cigarettes. According to Bullen et al. (59), serum levels of nicotine were similar after use of either the Nicotrol ${ }^{\circledR}$ inhaler or a Ruyan ${ }^{\circledR}$ e-cigarette. They found serum nicotine levels to peak at $1.3 \mathrm{ng} / \mathrm{ml}$ after $19.6 \mathrm{~min}$ of vaping an e-cigarette, and $2.1 \mathrm{ng} / \mathrm{ml}$ after 32 min of using the $\mathrm{Nicotrol}^{\circledR}$ inhaler, compared to $13.4 \mathrm{ng} / \mathrm{ml}$ after 14.3 min of smoking a cigarette. The Nicotrol ${ }^{\circledR}$ inhaler is said to be inappropriately named since it does not deliver significant quantities of nicotine directly to the lungs $(68,69)$. This is because the particle size of the delivered nicotine is too large to effectively reach pulmonary alveoli $(70,71)$. With each puff, the inhaler delivers nicotine to the oral cavity which is subsequently absorbed by the buccal mucosa and pharyngeal mucosa. It is not clear where 
Table 2 | Studies involving chemical analysis of e-cigarette cartridges, solutions, and mist.

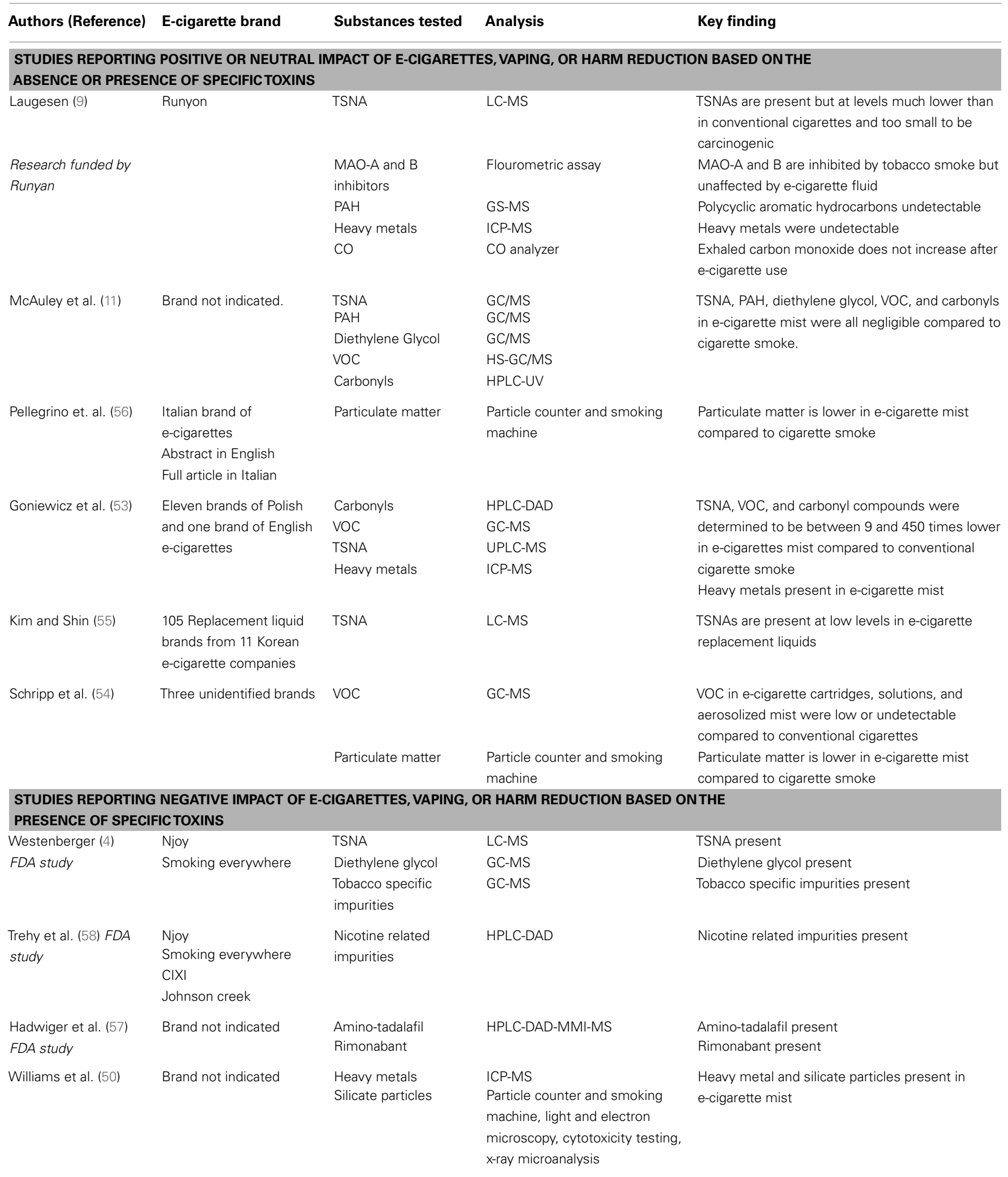

TSNA, tobacco specific nitrosoamines; LC-MS, liquid chromatography-mass spectrometry; MAO-A and B, monoamineoxidase A and B; PAH, polycyclic aromatic hydrocarbons; GS-MS, gas chromatography - mass spectrometry; ICP-MS, inductively coupled plasma - mass spectrometry; CO, carbon monoxide, VOC, volatile organic compounds; UPLC-MS, ultra-performance liquid chromatography-mass spectrometry; HPLC-DAD-MMI-MS, high performance liquid chromatography-diode array detector-multi-mode ionization-mass spectrometry. 
most of the nicotine from e-cigarettes is primarily absorbed; the alveoli, the airways or the oral cavity. In vitro evidence suggests that e-cigarette aerosol particle size and distribution in the respiratory system is similar to conventional cigarette smoke (72-74). Sahu et al. (72) found the particle size of mainstream cigarette smoke to range between 186 and $198 \mathrm{~nm}$ and deliveries to the pulmonary alveoli, tracheal, and bronchiolar airways, and oral cavity were predicted to be $29.8,15.2$, and $16.3 \%$, respectively. Zhang et al. (73) determined average e-cigarette aerosol particle diameters to be approximately $400 \mathrm{~nm}$, and alveolar deliveries to be between 7 and $18 \%$. Zhang et al. (73) also indicate that nicotine delivery is highly dependent on a number of factors, including vaping technique, particle evolution, and cloud effects. It is very likely that aerosol particle size and nicotine delivery via e-cigarettes may have similar distribution profiles that are intermediate between conventional cigarettes and the Nicotrol ${ }^{\circledR}$ inhaler.

In contrast to the aforementioned investigations $(59,66,67)$, three other study (75-77) found increased blood levels of nicotine in experienced e-cigarette users within $5 \mathrm{~min}$ of the first puff of an e-cigarette. Dawkins et al. (76) reported blood nicotine levels to increase from $0.74 \mathrm{ng} / \mathrm{ml}$ baseline to $6.77 \mathrm{ng} / \mathrm{ml} 10 \mathrm{~min}$ after 10 puffs of an e-cigarette, achieving a mean $13.91 \mathrm{ng} / \mathrm{ml}$ by the end of a 1-h ad libitum vaping period. It has also been reported that cotinine in the saliva (78) and serum (79) of e-cigarette users is significantly elevated to levels commonly found in cigarette smokers. Vansickel and Eissenberg (75) also reported an increase in heart rate, which is not surprising since smoking and nicotine have long been known to stimulate heart rate and blood pressure $(80,81)$. It is interesting to note that the 2010 Vansickel et al. (67) study, and in Czogala et al. (82), heart rate and nicotine levels were significantly increased in smokers, but not vapers. However, the 2013 Vansickel and Eissenberg study (75) reported that both smoking and vapinginduced similar concomitant increases in heart rate and blood levels of nicotine. As suggested by Farsalinos et al. (83), this discrepancy could be attributed to differences in experimental design, and puffing topography of the participants in each study (i.e., different daily durations of vaping, experience with e-cigarette devices, personal puffing characteristics to include the amount of vacuum created on every puff, and the vaping-induced deposition of nicotine into the oral cavity and/or size of the aerosolized particles). Trtchounian et al. (84), determined that smoke/aerosol density remained fairly constant while puffing on a conventional cigarette from start to finish (approximately 10 puffs), although variations did exist between brands of conventional cigarettes. The aerosol density for e-cigarettes, while higher than conventional cigarettes in three out of the four brands tested, also remained fairly constant for the first 10 puffs of a new e-cigarette cartridge. However, a decremental decrease in aerosol density was observed as each cartridge approached its terminal life. Consequently, this decrease in aerosol density would require the person vaping to generate more vacuum to maintain an aerosol density equivalent to the initial puffs and could be a reason contributing to longer puff duration for electronic cigarettes than for conventional cigarettes (85). Similar variations in the rate of airflow required to produce aerosol between and within brands of e-cigarettes were also reported by Williams and Talbot (86). According to Goniewicz et al. (52), these studies demonstrate the importance of the initial nicotine content, the efficiency of the vaporization process that determines how much of the nicotine gets aerosolized, and the individual's puffing topography on the efficacy of nicotine delivery from e-cigarettes.

Many smokers claim that smoking cigarettes increases cognitive awareness, reduces stress, and induces a pleasurable feeling of wellbeing. Consequently, this is what makes smoking cigarettes so enjoyable and addictive. It is suggested that smoking has some psychological beneficial effects relating to job performance, vigilance, and mnemonic tasks, and that these effects are induced by nicotine, the addictive ingredient in tobacco (87). Similar effects have also been noted in non-smokers after a single dose of nicotine (88), and it is also worth mentioning that nicotine may have an ameliorating effect on both Parkinson's and Alzheimer's patients (89). Dawkins et al. $(90,91)$ found a decrease in the desire to smoke and reduced withdrawal symptoms associated with tobacco abstinence (1-10 h) among smokers vaping e-cigarettes with nicotine in comparison to e-cigarettes without nicotine. Furthermore, the nicotine from the e-cigarette also improved prospective memory and working memory performance. Nicotine is a central nervous system (CNS) stimulant, and as such it is possible that a psychological need to enhance cognitive functioning reinforces addiction in smokers (92). Nicotine is also known to stimulate adrenergic and dopaminergic neurons in mesolimbic areas of the brain involved with reinforcing pleasurable reward behavior (93). Monoamine oxidases (MAO) normally reduce nicotine-induced adrenergic and dopaminergic activities by oxidizing them to inactive metabolites, and thereby limiting reward behavior. For cigarette smokers, however, nicotine is made even more addictive by synergizing with MAO inhibitors known to be present in cigarette smoke (94). Supporting evidence has been shown by Fowler et al. $(95,96)$ in which the activities of both MAO-A and MAO-B were reduced in various brain regions of smokers but not of non-smokers. Lewis et al. (94) indicate that there are at least six different MAO inhibitors present in cigarette smoke. In contrast, Laugesen et al. (9) were unable to detect any MAO inhibitors in e-cigarette cartridges or the inhaled aerosol mist. These studies suggest that nicotine from e-cigarettes and other FDA-approved NRTs may be less addictive than nicotine from burned tobacco products, and may be the reason why e-cigarette users report a suppression of smoking and nicotine cravings $(59,66,67,90,91)$. These investigations support the rationale behind NRT treatment for smoking cessation, which is that nicotine from NRTs, and possibly e-cigarettes, does not occupy the nicotinic receptors to the same extent as nicotine from tobacco smoke (97). The effect is reducing withdrawal symptoms and cravings for cigarettes $(71,98)$ while possibly still providing some enhanced cognitive awareness and pleasurable reward (92, 93). A summary of the studies involving nicotine content, delivery, and pharmacokinetics are listed in Table 3.

\section{CLINICAL AND PHYSIOLOGICAL EFFECTS OF ACUTE VAPING}

The harmful effects of smoking on human health are obvious and well documented. In contrast, effects of vaping on human health are inconclusive due to the extreme paucity of empirical research investigating the presence of vaping-induced health hazards and/or benefits. Few studies have actually reported deleterious effects of vaping. In one report, McCauley et al. (99) present a case 
Table 3 | Studies involving nicotine content, delivery, and pharmacokinetics.

\begin{tabular}{|c|c|c|c|c|}
\hline $\begin{array}{l}\text { Authors } \\
\text { (Reference) }\end{array}$ & $\begin{array}{l}\text { E-cigarette } \\
\text { brand }\end{array}$ & $\begin{array}{l}\text { Devices, substances or } \\
\text { parameters tested }\end{array}$ & Study design and analysis & Key finding \\
\hline \multicolumn{5}{|c|}{$\begin{array}{l}\text { STUDIES REPORTING POSITIVE } \\
\text { CIGARETTES AND SMOKING }\end{array}$} \\
\hline $\begin{array}{l}\text { Bullen et al. } \\
\text { (59) }\end{array}$ & & $\begin{array}{l}\text { Nicotine pharmacokinetic } \\
\text { profile was determined in ... } \\
\text { E-cigarette with } 16 \mathrm{mg} \\
\text { nicotine }(n=8) \\
\text { Nicotrol inhaler with } 10 \mathrm{mg} \\
\text { nicotine }(n=10) \\
\text { Participant's usual cigarette } \\
(n=9)\end{array}$ & $\begin{array}{l}\text { Plasma nicotine }(\mathrm{ng} / \mathrm{ml}) \text { was } \\
\text { determined by HPLC-EC in participants } \\
\text { who smoked at least } 10 \text { cigarettes/day }\end{array}$ & $\begin{array}{l}\text { Vaping e-cigarettes produce a } \\
\text { nicotine pharmacokinetic profile } \\
\text { very similar to the Nicotrol inhalers } \\
\text { but considerably lower than } \\
\text { smoking a cigarette }\end{array}$ \\
\hline $\begin{array}{l}\text { Eissenberg } \\
(66)\end{array}$ & $\begin{array}{l}\text { Njoy } \\
\text { Crown seven }\end{array}$ & $\begin{array}{l}\text { Plasma nicotine and heart } \\
\text { rate measured before and } \\
\text { after } 10 \text { puffs of each device } \\
\text { was determined in the } \\
\text { following groups ... } \\
\text { Njoy ( } 16 \text { mg nicotine) } \\
\text { Crown seven ( } 16 \text { mg nicotine) } \\
\text { own brand cigarette } \\
\text { Sham own brand cigarette }\end{array}$ & $\begin{array}{l}\text { Sixteen smokers, naïve to e-cigarettes } \\
\text { were cycled through the four device } \\
\text { groups. Participants were required to } \\
\text { have a 12-h period of cigarette } \\
\text { abstinence before the start of each } \\
\text { device test and 48-h between each } \\
\text { device test }\end{array}$ & $\begin{array}{l}\text { Smoking, but not vaping, } \\
\text { significantly increased plasma } \\
\text { nicotine and heart rate }\end{array}$ \\
\hline $\begin{array}{l}\text { Vansickel et al. } \\
\text { (67) }\end{array}$ & $\begin{array}{l}\text { Njoy } \\
\text { Crown seven }\end{array}$ & $\begin{array}{l}\text { Plasma nicotine, expired } \\
\text { carbon monoxide and heart } \\
\text { rate measured before and } \\
\text { after } 10 \text { puffs of each device } \\
\text { were determined in the } \\
\text { following groups ... } \\
\text { Njoy (18 mg nicotine) } \\
\text { Crown seven ( } 16 \text { mg nicotine) } \\
\text { Own brand cigarette } \\
\text { Sham own brand cigarette }\end{array}$ & $\begin{array}{l}\text { Sixteen smokers, naïve to e-cigarettes } \\
\text { were cycled through the four device } \\
\text { groups. Participants were required to } \\
\text { have a 12-h period of cigarette } \\
\text { abstinence before the start of each } \\
\text { device test and } 48 \text {-h between each } \\
\text { device test }\end{array}$ & $\begin{array}{l}\text { Plasma levels of nicotine, expired } \\
\text { carbon monoxide, and heart rate all } \\
\text { increased after smoking, but not } \\
\text { vaping }\end{array}$ \\
\hline $\begin{array}{l}\text { Czogala et al. } \\
\text { (82) }\end{array}$ & $\begin{array}{l}\text { Brand not } \\
\text { indicated } \\
\text { Abstract in } \\
\text { English Full article } \\
\text { In Polish }\end{array}$ & $\begin{array}{l}\text { Systolic pressure } \\
\text { Diastolic pressure } \\
\text { Pulse } \\
\text { Heart rate }\end{array}$ & $\begin{array}{l}\text { Comparison of hemodynamic } \\
\text { parameters in smokers ( } n=42 ; 50 \% \\
\text { male) after smoking a cigarette or } \\
\text { vaping an e-cigarette }\end{array}$ & $\begin{array}{l}\text { Vaping e-cigarettes failed to induce } \\
\text { the typical hemodynamic } \\
\text { parameters associated with } \\
\text { traditional smoking }\end{array}$ \\
\hline $\begin{array}{l}\text { Dawkins et al. } \\
\text { (91) }\end{array}$ & White Super & $\begin{array}{l}\text { Desire to smoke } \\
\text { Nicotine withdrawal } \\
\text { symptoms } \\
\text { Attention and working } \\
\text { memory was determined in } \\
\text { the following groups ... } \\
\text { E-cigarette (18 mg nicotine) } \\
\text { E-cigarette (0 mg nicotine) } \\
\text { Just hold e-cigarette }\end{array}$ & $\begin{array}{l}\text { Random allocation of } 86 \text { smokers into } \\
\text { one of three groups. Desire to smoke } \\
\text { and withdrawal symptoms rated at } 0 \text {, } \\
5 \text {, and } 20 \text { min after vaping ad libitum for } \\
5 \text { min. Attention and working memory } \\
\text { was determined using "The Letter } \\
\text { Cancelation" and "Brown-Peterson } \\
\text { Working Memory" tests }\end{array}$ & $\begin{array}{l}\text { E-cigarettes eliminated nicotine } \\
\text { withdrawal symptoms and desire to } \\
\text { smoke and enhanced working } \\
\text { memory performance, suggesting } \\
\text { efficient nicotine delivery }\end{array}$ \\
\hline
\end{tabular}


Table 3 | Continued

\begin{tabular}{|c|c|c|c|}
\hline $\begin{array}{l}\text { Authors } \\
\text { (Reference) }\end{array}$ & $\begin{array}{l}\text { E-cigarette } \\
\text { brand }\end{array}$ & $\begin{array}{l}\text { Devices, substances or } \\
\text { parameters tested }\end{array}$ & Study design and analysis \\
\hline $\begin{array}{l}\text { Ingebrethesen } \\
\text { et al. (74) }\end{array}$ & $\begin{array}{l}\text { Two different } \\
\text { brands not } \\
\text { specified }\end{array}$ & $\begin{array}{l}\text { E-cigarette aerosol particle } \\
\text { size } \\
\text { Cigarette smoke particle size }\end{array}$ & $\begin{array}{l}\text { Smoking machine and spectral } \\
\text { transmission procedure }\end{array}$ \\
\hline $\begin{array}{l}\text { Vansickel et al. } \\
\text { (77) }\end{array}$ & Vapor king & $\begin{array}{l}\text { Plasma nicotine } \\
\text { concentration, heart rate, } \\
\text { urge to smoke cigarette, and } \\
\text { nicotine withdrawal } \\
\text { symptoms tested in four } \\
\text { sessions. Session 1: } 10 \text { puffs } \\
\text { of e-cigarette; Session } 2 \text { : } \\
\text { choice of } 10 \text { puffs of } \\
\text { e-cigarette or cash; Session } 3 \text { : } \\
\text { choice of } 10 \text { puffs of } \\
\text { e-cigarette or } 10 \text { puffs of } \\
\text { conventional cigarette; } \\
\text { Session } 4 \text { : choice of } 10 \text { puffs } \\
\text { of conventional cigarette or } \\
\text { cash. Each session consisted } \\
\text { of } 6 \text { bouts of puffing and } \\
\text { bouts were } 30 \text { min apart }\end{array}$ & $\begin{array}{l}\text { Twenty smokers, not currently using } \\
\text { e-cigarettes, were cycled through four } \\
\text { experimental sessions. Participants } \\
\text { were required to have a 12-h period of } \\
\text { cigarette abstinence before the start of } \\
\text { each device test and 48-h between } \\
\text { each device test } \\
\text { No mention of how nicotine was } \\
\text { assayed }\end{array}$ \\
\hline
\end{tabular}

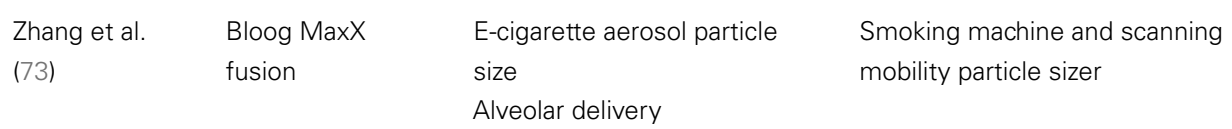

Dawkins and First-generation Plasma nicotine Fourteen experienced e-cigarette users Corcoran (76) e-cigarette (18 $\mathrm{mg} / \mathrm{ml}$ nicotine)

Dawkins et al. Tornado (90)

Etter et al. (63) Twenty models of the 10 most popular brands of refill liquids for e-cigarettes

abstinent from smoking and vaping for $12 \mathrm{~h}$ before test period

Blood samples collected at baseline (0 min), after 10 puffs, after $1 \mathrm{~h}$ ad libitum, and after a 2 -h rest period

Twenty smokers, abstinent for 8-10 h, cycled through two experimental sessions. Desire to smoke was determined using "Single-Item Desire to Smoke Scale" and "Mood and

Session 1: e-cigarette (18 mg nicotine)

Session 2: e-cigarette $10 \mathrm{mg}$ nicotine)

Physical Symptoms Scale."

Prospective memory was measured using "Cambridge Prospective Memory Test"

GC and LC

\section{Key finding}

Particle size in e-cigarette aerosol and conventional cigarette smoke for nicotine delivery are similar

E-cigarettes deliver significant amounts of nicotine, increase heart rate, and reduce nicotine withdrawal symptoms and the urge to smoke

E-cigarette aerosol particle diameter was slightly larger and calculated alveolar delivery is slightly lower when compared to cigarette smoke. Nicotine delivery depends on vaping technique, particle evolution, and cloud effect

The nicotine content in refill bottles are close to what is indicated on the label. Impurities in several brands are detectable but at levels considered harmless 
Table 3 | Continued

\begin{tabular}{|c|c|c|c|c|}
\hline $\begin{array}{l}\text { Authors } \\
\text { (Reference) }\end{array}$ & $\begin{array}{l}\text { E-cigarette } \\
\text { brand }\end{array}$ & $\begin{array}{l}\text { Devices, substances or } \\
\text { parameters tested }\end{array}$ & Study design and analysis & Key finding \\
\hline $\begin{array}{l}\text { Farsalinos } \\
\text { et al. (83) }\end{array}$ & Nobacco & $\begin{array}{l}\text { Puff number and duration, } \\
\text { inhalation time, exhalation } \\
\text { time, and nicotine consumed } \\
\text { was determined in the } \\
\text { following groups ... } \\
\text { E-cigarette users (vaping) } \\
\text { Smokers (smoking and vaping } \\
\text { subgroups) }\end{array}$ & $\begin{array}{l}\text { Forty-five e-cigarette users and } 35 \\
\text { smokers (smokers were in a } \\
\text { randomized cross-over design) were } \\
\text { observed for puff number and duration, } \\
\text { and inhalation and exhalation times } \\
\text { using video recordings. Nicotine } \\
\text { consumed (e-cigarette group only) was } \\
\text { measured by loss of weight of liquid in } \\
\text { cartridge using a precision balance }\end{array}$ & $\begin{array}{l}\text { E-cigarette use topography and } \\
\text { conventional cigarette use } \\
\text { topography are different. At least } \\
20 \mathrm{mg} / \mathrm{ml} \text { nicotine in e-cigarette } \\
\text { liquid is required to deliver the same } \\
\text { amount of nicotine as conventional } \\
\text { cigarettes }\end{array}$ \\
\hline $\begin{array}{l}\text { Flouris et al. } \\
\text { (79) }\end{array}$ & Nobacco & $\begin{array}{l}\text { Serum cotinine was } \\
\text { determined in .... } \\
\text { Smokers } \\
\text { Never smokers }\end{array}$ & $\begin{array}{l}\text { Smokers ( } n=15 \text { ) went through a } \\
\text { control session, an active smoking } \\
\text { session, and an active vaping session. } \\
\text { Never smokers went through control, } \\
\text { passive smoking and passive vaping } \\
\text { sessions. LC-MC used to measure } \\
\text { serum cotinine }\end{array}$ & $\begin{array}{l}\text { Acute vaping and acute smoking } \\
\text { induce similar increases in serum } \\
\text { cotinine levels }\end{array}$ \\
\hline $\begin{array}{l}\text { Goniewicz } \\
\text { et al. (52) }\end{array}$ & $\begin{array}{l}\text { Sixteen popular } \\
\text { brands of } \\
\text { e-cigarettes from } \\
\text { Poland, United } \\
\text { Kingdom, and } \\
\text { United States }\end{array}$ & $\begin{array}{l}\text { Nicotine content in e-cigarette } \\
\text { aerosol }\end{array}$ & $\begin{array}{l}\text { E-cigarette aerosol was generated } \\
\text { using smoking machine. Nicotine } \\
\text { content in aerosol was determined } \\
\text { using GS-TSD }\end{array}$ & $\begin{array}{l}\text { Nicotine in e-cigarette aerosol is } \\
\text { lower than in cigarette smoke. } \\
\text { Efficacy and consistency of nicotine } \\
\text { vaporization between brands is } \\
\text { variable }\end{array}$ \\
\hline Hua et al. (85) & Various brands & $\begin{array}{l}\text { Puff duration } \\
\text { Exhalation duration }\end{array}$ & $\begin{array}{l}\text { Analysis of Youtube videos of nine } \\
\text { conventional smokers and } 64 \\
\text { e-cigarette users }\end{array}$ & $\begin{array}{l}\text { Longer puff durations may help } \\
\text { e-cigarette users to compensate for } \\
\text { poor nicotine delivery }\end{array}$ \\
\hline $\begin{array}{l}\text { Vansickel and } \\
\text { Eissenberg } \\
\text { (75) }\end{array}$ & Own brand & $\begin{array}{l}\text { Plasma nicotine } \\
\text { Heart rate } \\
\text { Experienced e-cigarette users } \\
(n=8)\end{array}$ & $\begin{array}{l}\text { Blood samples were collected at } \\
\text { baseline }(0 \mathrm{~h}) \text {, after } 10 \text { puffs, after } 1 \mathrm{~h} \\
\text { ad libitum puffing, and after a } 2 \text {-h rest } \\
\text { period }\end{array}$ & $\begin{array}{l}\text { Vaping and smoking induce similar } \\
\text { increases in plasma nicotine and } \\
\text { heart rate }\end{array}$ \\
\hline
\end{tabular}

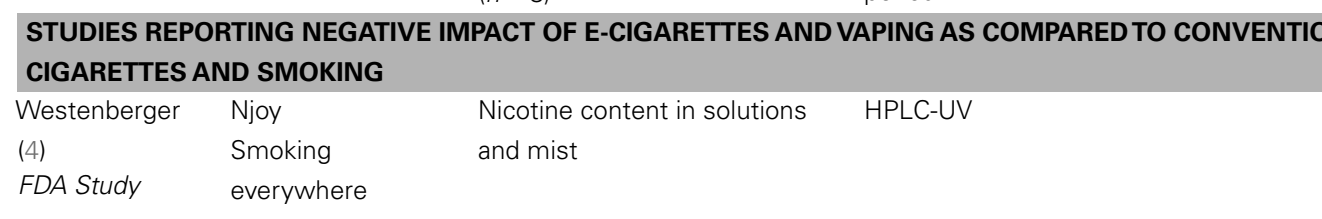

\begin{tabular}{|c|c|c|c|c|}
\hline $\begin{array}{l}\text { Hadwiger } \\
\text { et al. (57) } \\
\text { FDA Study }\end{array}$ & $\begin{array}{l}\text { Brand not } \\
\text { indicated }\end{array}$ & Nicotine content in solutions & HPLC-UV & $\begin{array}{l}\text { Presence of nicotine in products } \\
\text { labeled as containing no nicotine }\end{array}$ \\
\hline $\begin{array}{l}\text { Trtchounian } \\
\text { et al. (84) }\end{array}$ & $\begin{array}{l}\text { Liberty stix } \\
\text { Smoking } \\
\text { everywhere } \\
\text { Njoy } \\
\text { Crown seven } \\
\text { versus eight } \\
\text { brands of } \\
\text { conventional } \\
\text { cigarettes }\end{array}$ & $\begin{array}{l}\text { Vacuum required for each puff } \\
\text { Aerosol or smoke density }\end{array}$ & $\begin{array}{l}\text { Manometer coupled to smoking } \\
\text { machine } \\
\text { Absorbance measurement using a } \\
\text { spectrophotometer }\end{array}$ & $\begin{array}{l}\text { More vacuum required to vape than } \\
\text { to smoke. Smoke and aerosol } \\
\text { density remained stable for } \\
\text { conventional and e-cigarettes over } \\
\text { the first } 10 \text { puffs. Aerosol density } \\
\text { for e-cigarettes gradually decreased } \\
\text { as e-cigarette life extended to } 300 \\
\text { puffs. This is reflected by a gradual } \\
\text { increase in vacuum required for } \\
\text { each puff on the e-cigarette. }\end{array}$ \\
\hline
\end{tabular}

The nicotine in several e-cigarette solutions is too variable to be considered safe. The amount of nicotine delivered per puff is inconsistent 
Table 3 | Continued

\begin{tabular}{|c|c|c|c|c|}
\hline $\begin{array}{l}\text { Authors } \\
\text { (Reference) }\end{array}$ & $\begin{array}{l}\text { E-cigarette } \\
\text { brand }\end{array}$ & $\begin{array}{l}\text { Devices, substances or } \\
\text { parameters tested }\end{array}$ & Study design and analysis & Key finding \\
\hline $\begin{array}{l}\text { Trehy et al. (58) } \\
\text { FDA Study }\end{array}$ & $\begin{array}{l}\text { Njoy } \\
\text { Smoking } \\
\text { everywhere } \\
\text { CIXI } \\
\text { Johnson Creek }\end{array}$ & $\begin{array}{l}\text { Nicotine content in solutions } \\
\text { and nicotine delivery/puff }\end{array}$ & $\begin{array}{l}\text { HPLC-UV } \\
\text { Smoking machine }\end{array}$ & $\begin{array}{l}\text { Nicotine in e-cigarette cartridges } \\
\text { and refill solutions is inaccurately } \\
\text { labeled and nicotine content varies } \\
\text { by manufacturer. The amount of } \\
\text { nicotine delivered per puff is } \\
\text { consistent. }\end{array}$ \\
\hline $\begin{array}{l}\text { Trtchounian } \\
\text { and Talbot (65) }\end{array}$ & $\begin{array}{l}\text { Njoy } \\
\text { Ncig } \\
\text { Liberty stix } \\
\text { Crown seven } \\
\text { Smoking } \\
\text { everywhere } \\
\text { VapCigs }\end{array}$ & $\begin{array}{l}\text { Design flaws and defective } \\
\text { parts } \\
\text { Labels on cartridges, and } \\
\text { wrappers } \\
\text { Leakiness of cartridges } \\
\text { Disposal documentation } \\
\text { Errors in filling of mail orders } \\
\text { Instruction manual } \\
\text { Truth in advertisement }\end{array}$ & $\begin{array}{l}\text { E-cigarettes were purchased online. } \\
\text { Information about the parameters } \\
\text { inspected was obtained via e-mail to } \\
\text { vendors or by visual inspection of the } \\
\text { product and product literature }\end{array}$ & $\begin{array}{l}\text { Design flaws, lack of adequate } \\
\text { labeling, concerns about control and } \\
\text { health issues argue for removal of } \\
\text { e-cigarettes from the market }\end{array}$ \\
\hline $\begin{array}{l}\text { Williams and } \\
\text { Talbot (86) }\end{array}$ & Various brands & $\begin{array}{l}\text { Airflow rate required to } \\
\text { produce aerosol } \\
\text { Pressure drop } \\
\text { Aerosol density }\end{array}$ & $\begin{array}{l}\text { Airflow meter } \\
\text { Manometer } \\
\text { Absorbance measurement using a } \\
\text { spectrophotometer }\end{array}$ & $\begin{array}{l}\text { Significant variability exists between } \\
\text { and within brands of e-cigarettes in } \\
\text { the airflow rate required to produce } \\
\text { aerosol, the pressure drop, the } \\
\text { length of time cartridges last, and } \\
\text { production of aerosol }\end{array}$ \\
\hline $\begin{array}{l}\text { Cheah et al. } \\
(60)\end{array}$ & $\begin{array}{l}\text { Twenty different } \\
\text { brands of } \\
\text { e-cigarettes }\end{array}$ & $\begin{array}{l}\text { Nicotine content in cartridges } \\
\text { E-cigarettes quality and } \\
\text { documentation }\end{array}$ & $\begin{array}{l}\text { GC-MS } \\
\text { Visual inspection of the product and } \\
\text { product literature }\end{array}$ & $\begin{array}{l}\text { Variable nicotine content in } \\
\text { cartridges of the same brand, and } \\
\text { inconsistency with product labeling, } \\
\text { along with misleading information } \\
\text { on labels raises concern about } \\
\text { e-cigarette safety }\end{array}$ \\
\hline $\begin{array}{l}\text { Cameron et al. } \\
\text { (62) }\end{array}$ & $\begin{array}{l}\text { Brands of } \\
\text { e-cigarette } \\
\text { nicotine solutions } \\
\text { and cartridges } \\
\text { tested include... } \\
\text { Vapor liquid } \\
\text { No Brand liquid } \\
\text { Smart Smoke } \\
\text { liquid } \\
\text { BE112 cartridge } \\
\text { Vapor cartridge }\end{array}$ & $\begin{array}{l}\text { Nicotine content in solutions } \\
\text { and cartridges }\end{array}$ & LC-MS & $\begin{array}{l}\text { Nicotine levels in e-cigarette } \\
\text { solutions were too variable to be } \\
\text { considered safe }\end{array}$ \\
\hline
\end{tabular}

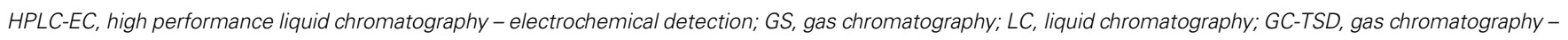
thermionic specific detection; HPLC-UV, high performance liquid chromatography - ultraviolet detection; GS-MS, gas chromatography - mass spectrometry; LC-MS, liquid chromatography-mass spectrometry; NRT, nicotine replacement therapy.

study concerning a 42-year-old woman diagnosed with exogenous lipoid pneumonia due to e-cigarette use. She presented with a 7month history of dyspnea, productive cough, and fevers which coincided with her use of e-cigarettes. Samples of her sputum, and bronchoalveolar lavage revealed lipid-laden macrophages. Glycerin, an ingredient added to e-cigarette solutions for the purpose of producing visual smoke when vaping, was thought to be the causative agent. Computed axial tomography (CAT) images of her lungs revealed areas of patchy ground glass superimposed on interlobular septal thickening, a pattern typical of a restrictive ventilatory defect with diffusion impairment, and consistent with the patient's diagnosis. Cessation of e-cigarette use resulted in improvement of her symptoms that was verified by follow-up lung radiography, however, pulmonary function testing still indicated 
mild diffusion impairment. Since the case study does not reveal if the patient is a current or ex-smoker and for how long, it is unclear whether the persistent diffusion impairment is a result of a concurrent or previous smoking habit, the use of e-cigarettes, or the after effects of lipoid pneumonia per se. In another report, Vardavas et al. (100) found that $5 \mathrm{~min}$ of acute vaping among healthy smokers had no effect on basic pulmonary parameters [i.e., forced expiratory volume in $1 \mathrm{~s}\left(\mathrm{FEV}_{1}\right)$, forced vital capacity (FVC), peak expiratory flow (PEF), or midexpiratory flows at 50 $\left(\mathrm{MEF}_{50}\right)$ and $75\left(\mathrm{MEF}_{75}\right)$ percent]. This is in agreement Flouris et al. (79) who reported the $\mathrm{FEV}_{1} / \mathrm{FVC}$ ratio after acute vaping to be non-significantly reduced by $3.0 \%$ (79). This study, also reported the $\mathrm{FEV}_{1} / \mathrm{FVC}$ ratio after acute tobacco smoking to be significantly reduced by $7.2 \%$. Vardavas et al. (100) did find decreased amounts of exhaled nitric oxide and increased peripheral airway resistance and impedance in smokers who vaped for $5 \mathrm{~min}$. From these results they concluded that acute vaping has "immediate adverse physiological effects similar to some of the effects observed with smoking" but that the long-term health effects of vaping are not known and potentially harmful. The authors went on to qualify their conclusion by stating that although the differences in exhaled nitric oxide, airway resistance, and impedance were statistically significant, the differences are probably not clinically important. It is possible that the increased airway resistance and impedance demonstrated by Vardavas et al. (100) is partially due to the nicotine inhaled from the e-cigarettes. Evidence for this is seen in a study reporting that non-smokers who inhaled nicotine $(0-64 \mathrm{mg} / \mathrm{ml})$ showed a dose-dependent increase in both the amount of coughing and airway obstruction, suggesting that nicotine stimulates afferent nerve endings in the bronchial mucosa which then triggers parasympathetic cholinergic pathways leading to bronchoconstriction (101).

In recent years there has been an effort to clinically use exhaled nitric oxide as an important non-invasive adjunct to pulmonary function testing (102) in order to monitor the degree of airway inflammation and eosinophilia $(103,104)$ commonly observed in conditions such as asthma. Unfortunately, interpretation of exhaled nitric oxide levels in the clinical setting is complex and confusing requiring adjustments for gender, age, height, respiratory infection, allergies, and smoking $(105,106)$. Given these difficulties, its validity is controversial. The major consensus in the literature is that the amount of exhaled nitric oxide is reduced in long-time smokers, as compared to non-smokers (105-109). In addition, it has been shown that smoking cessation is associated with an increase in exhaled nitric oxide back toward non-smoker levels (110). A possible mechanism of action for the opposing relationship of exhaled nitric oxide in smokers versus non-smokers could be the high levels of carbon monoxide present in cigarette smoke since there is strong evidence suggesting that carbon monoxide inhibits nitric oxide production by blocking nitric oxide synthase activity $(111,112)$. This mechanism is unlikely to occur with long-term vaping since carbon monoxide levels in e-cigarette mist are negligible (9). In any case, there is no available literature showing the long-term effects of vaping on exhaled nitric oxide or carbon monoxide, although Caponnetto et al. (113) did show exhaled carbon monoxide levels to decrease from 31 to $4 \mathrm{ppm}, 29$ to $2 \mathrm{ppm}$, and 35 to $5 \mathrm{ppm}$ in three individuals who first successfully transitioned from conventional cigarettes to e-cigarettes and then quit e-cigarettes altogether. The first time carbon monoxide was measured, all individuals were heavy smokers ( 45 pack/year, 28 pack/year, and 89 pack/year histories). The final time that exhaled carbon monoxide was measured all individuals had been smoke- and vape-free for nearly 2 years. Using an experimental group of "healthy" smokers, Vardavas et al. (100) reported a decreased fraction of exhaled nitric oxide (FENO) after just $5 \mathrm{~min}$ of vaping (from 13.02 to $10.89 \mathrm{ppb}$ ) which they correlated with airway inflammation and oxidative stress. In their introduction they state that "smokers have significantly lower concentrations of FENO - a non-invasive marker of bronchial inflammation - compared with non-smokers." On the other hand, in their discussion they state that "nitric oxide is an additional marker that has been implicated in the pathophysiology of airway diseases associated with smoking, is strongly correlated with eosinophilic inflammation and bronchial hyperactivity, and has become an established marker for assessing oxidative stress, indicating the immediate effect e-cigarette usage might have on pulmonary homeostasis." From these two statements and from their FENO results, it is unclear whether they mean that smoking and vaping produce less bronchial inflammation and oxidative stress or more bronchial inflammation and oxidative stress when compared to not smoking or not vaping.

Although base levels of nitric oxide tend to be lower in smokers compared to non-smokers, Chambers et al. (114) observed significant increases in exhaled nitric oxide from $2.6 \mathrm{ppb}$ before smoking to $4.8 \mathrm{ppb} 1 \mathrm{~min}$ and $3.2 \mathrm{ppb} 10 \mathrm{~min}$ after smoking a cigarette. Buda et al. (115) reported FENO to be 18,29 , and $16 \%$ higher than baseline 30,45 , and $60 \mathrm{~min}$ after smoking a cigarette, respectively. The findings of Vardavas et al. (100) concerning FENO levels after acute vaping are in direct opposition to what has been observed immediately after smoking a cigarette $(114,115)$. These results clearly demonstrate that acute vaping and acute smoking affect pulmonary nitric oxide metabolism, and the associated airway inflammatory responses, differently. From the available literature it is not clear how vaping might affect pulmonary inflammatory processes, but, as previously indicated, glycerin has been linked to lipoid pneumonia (99), and nicotine is known to generate endothelial dysfunction and systemic inflammation (16). Propylene glycol mist has been shown to produce ocular and respiratory irritation (116), and increase the risk of acquiring asthma (117), although Robertson et al. (118) reported that long-term inhalation of propylene glycol vapor by both monkeys and rats produced no deleterious pulmonary effects and Laugesen et al. (9) found no ill effects in humans. Bahl et al. (119) investigated the effects of a number of e-cigarette refill fluids on cultured human embryonic stem cells (hESCs), and human pulmonary fibroblasts (hPFs) and found that nicotine in e-cigarette refill fluids had no effect on hESC or hPF cytotoxicity at any concentration. However, they did report a positive correlation between hESC cytotoxicity, and the number and concentration of other chemicals used to flavor ecigarette refill fluids. Similar results were published by Romagna et al. (120) who demonstrated that an extract of e-cigarette mist was less cytotoxic to cultured murine fibroblasts than an extract of 
Table 4 | Studies involving clinical and physiological effects of acute vaping.

\begin{tabular}{llll}
\hline Authors (Reference) & Study design & Subjects & Study location \\
\hline \multicolumn{2}{l}{ STUDIES REPORTING POSITIVE OR NEUTRAL IMPACT OF E-CIGARETTES AND VAPING ON HEALTH } \\
Caponnetto et al. & Three case & A 47-year old male & University of Catania, Catania, Italy \\
(113) & reports & A 38-year old female & \\
& & A 65-year old male
\end{tabular}

Bahl et al. (119) In vitro

cultures

Human embryonic stem cells, and pulmonary fibroblasts

University of California, Riverside, California

Romagna (123) (8 male) cycled through a
FAME Laboratory, Institute of Rehabilitation, Center for Research and Technology, Trikala, Greece Larissa, Greece Palamas Health Center, Kardista, Greece

University of Botswana, Botswana University of Crete, Crete, Greece University of Wolverhampton, United Kingdom

Onasis Cardiac Surgery Center, Kallithea, Greece and Abich $\mathrm{ABICH}$ S.r.l. Toxicological Laboratory, Verbania, Italy

FAME Laboratory, Institute of Human Performance and Rehabilitation, Center for Research and Technology, Trikala, Greece Human Performance and University of Thessaly, Trikala, and
ABICH S.R.L. Toxicological

Laboratory, Verbania, Italy

$\begin{array}{ll}\text { Flouris et al. (121) } \quad & \text { Repeated- } \\ & \text { measures } \\ & \text { controlled } \\ \text { study }\end{array}$

Farsalinos and Case report

Romagna et al. (120) In vitro

cultures

Thirty human smokers

(8 male) cycled through a control session, active smoking session, and active vaping session Fifteen never smokers control session, passive smoking session and passive vaping session

A 28-year old male with
chronic iodiopathic
neutrophilia
neutrophilia

Thirty human smokers (8 male) cycled through a control session, active smoking session and active vaping session. Fifteen never smokers (8 male) cycled through a control session, passive smoking session, and passive vaping session

Murine Fibroblasts

\section{STUDIES REPORTING NEGATIVE IMPACT OF E-CIGARETTES AND VAPING ON HEALTH}

Bahl et al. (119)

In vitro

cultures

Human embryonic stem cells,

and pulmonary fibroblasts

California

McCauly et al. (99) Case report

A 42-year woman with exogenous lipoid pneumonia

Vardavas et al. (100) Laboratorybased Active vaping (experimental) for 5 min in smokers (14 men) versus passive vaping (control) for $5 \mathrm{~min}$ in 10 smokers randomly selected from the experimental group

intervention study

\section{Key finding}

Participants successfully switched from conventional cigarettes to e-cigarettes and then quit e-cigarettes. Smoking cessation confirmed by exhaled carbon monoxide

Nicotine in e-cigarette refill fluids had no effect on the cytotoxicity of human embryonic stem cells

Acute smoking, but not acute vaping, induced increases in white blood cell count, lymphocyte count and granulocyte count

Smoking cessation and e-cigarette use reversed symptoms of chronic iodiopathic neutrophilia. Smoking cessation was confirmed by exhaled carbon monoxide

Vaping produced smaller changes in pulmonary function but similar nicotinergic impact compared to smoking
Extract of e-cigarette mist is less cytotoxic than extract of cigarette smoke to murine fibroblasts
Legacy Good Samaritan Medical Center, Portland, Oregon

Participants from a community in Athens, Greece

The number and concentration of chemicals (other than nicotine) used to flavor e-cigarette refill fluids increased cytotoxicity

Termination of e-cigarette use cleared the exogenous lipoid pneumonia

Five minutes acute vaping-induced a decrease in exhaled nitric oxide, and an increase in airway resistance and impedance in experienced smokers 
tobacco cigarette smoke. A further indication that there are differences in the inflammatory responses between vapers and smokers is illustrated in a study reporting an absence of increased inflammatory indices in smokers asked to vape for $30 \mathrm{~min}$ compared to smokers who were asked to smoke for $30 \mathrm{~min}$ (121). Acute smoking has long been known to increase white blood cell count, which is a sign of acute inflammatory load (122). Flouris et al. (121) were able to confirm elevations of white blood cell count, lymphocyte count, and granulocyte count in active smokers but not in active vapers. Support for this is seen in a recently published case report (123) where a 36-year-old male with a nine packyear history of smoking exhibited reversal of chronic idiopathic neutrophilia symptoms after he quit smoking and started vaping. Table 4 summarizes the studies involving clinical and physiological effects of acute vaping.

\section{CONCLUSION}

Despite the popularity e-cigarettes have gained worldwide, very little rigorous research has been done regarding the effects these devices have on human health. This article reviews the existing evidence-based literature, dealing with surveys soliciting personal views on vaping; studies analyzing potential toxins and contaminants in e-cigarette cartridges, solutions, and mist; reports profiling nicotine content, delivery, and pharmacokinetics; and clinical and physiological studies investigating the effects of acute vaping. When compared to the harmful effects of smoking, these studies suggest that vaping could be used as a possible "harm reduction" tool. There is evidence supporting e-cigarettes as an aide for smoking cessation, at least as successful as currently available FDA-approved NRTs. Less evidence exists to suggest that e-cigarettes are effective in recovery from nicotine dependence. More rigorous research is essential before any solid conclusions can be drawn about the dangers, or usefulness of e-cigarettes. In particular, more rigorous research is required delving into both acute and long-term cardiopulmonary effects of vaping, especially those experiments comparing the effects of vaping with those of smoking. E-cigarettes are fast becoming a new "tobacco" industry (124) that could reduce the incidence of traditional smoking. It is also possible that e-cigarettes may either decrease or increase the incidence of nicotine addiction. Given these uncertainties, will the availability of e-cigarettes provide for healthier U.S. and world populations, as harm reductionists hope, or will other more dangerous ill effects ultimately emerge? Health care professionals must remain current with the literature concerning e-cigarettes and vaping. Only then can they make informed decisions aimed at maximizing human safety and minimizing the potential ill effects e-cigarettes may have on their patients and the public. Only then can the new challenge regarding e-cigarettes and vaping in clinical medicine and public health be adequately addressed.

\section{ACKNOWLEDGMENTS}

The author would like to thank the faculty and staff of the DeBusk College of Osteopathic Medicine, Lincoln Memorial University for graciously providing constructive criticism, comments, and editorial assistance in the preparation of this manuscript.

\section{REFERENCES}

1. Modi N, Schmid B, Miller R. Clearing the Smoke on e-Cigarettes. New York, NY: UBS Securities LLC (2012). Available from: http://www.stevevape.com/ wp-content/uploads/2012/05/Clearing-the-Smoke-on-E-Cigarettes.pdf

2. Woodcock J. Letter to Mr. Matt Salmon, President, Electronic Cigarette Association. (2013). Available from: http://www.fda.gov/downloads/Drugs/ GuidanceComplianceRegulatoryInformation/UCM225263.pdf

3. Electronic Cigarette Consumer Reviews (ECCR). ECCR. (2013). Available from: http://www.electroniccigaretteconsumerreviews.com/about-us

4. Westenberger BJ. Evaluation of e-Cigarettes. St. Louis, MO: Department of Health and Human Services, Food and Drug Administration, Center for Drug Evaluation and Research, Division of Pharmaceutical Analysis (2009). Available from: http://www.fda.gov/downloads/drugs/Scienceresearch/ UCM173250.pdf

5. Pandemic and All-Hazards Preparedness Reauthorization Act of 2013 Federal Food, Drug and Cosmetic Act as Amended through 2013, Pub L No 113-5, 127 Stat 161 (2013). Available from: http://www.gpo.gov/fdsys/pkg/ PLAW113publ5/pdf/PLAW-113publ5.pdf

6. Smoking Everywhere, Inc. v. U.S. Food and Drug Administration and U.S. Department of Health and Human Services, 1:09-cv-00771-RJL (D DC 2009). Available from: http://www.fdalawblog.net/files/smoking-everywhere-tro.pdf

7. Sottera Inc., Doing Business as NJOY v. Food and Drug Administration, et al. (DC Cir 2010). Available from: http://www.cadc.uscourts. gov/internet/opinions.nsf/D02F9D2CA50299F0852577F20070BCC2/\$file/ 10-5032-1281606.pdf

8. U.S. FDA. Electronic cigarettes (e-cigarettes). News Events. (2013). Available from: http://www.fda.gov/NewsEvents/PublicHealthFocus/ucm172906.htm

9. Laugesen M. Safety Report on the Ruyan ${ }^{\circledR}$ e-Cigarette and Inhaled Aerosol. Christchurch: Health New Zealand Ltd (2008). Available from: http://www. healthnz.co.nz/RuyanCartridgeReport30-Oct-08.pdf

10. Cahn Z, Siegel M. Electronic cigarettes as a harm reduction strategy for tobacco control: a step forward or a repeat of past mistakes? J Public Health Policy (2011) 32:16-31. doi:10.1057/jphp.2010.41

11. McAuley TR, Hopke PK, Zhao J, Babaian S. Comparison of the effects of ecigarette vapor and cigarette smoke on indoor air quality. Inhal Toxicol (2012) 24:850-7. doi:10.3109/08958378.2012.724728

12. Foulds J, Veldheer S, Berg A. Electronic cigarettes (e-cigs): views of aficionados and clinical/public health perspectives. Int J Clin Pract (2011) 65:1037-42. doi:10.1111/j.1742-1241.2011.02751.x

13. Foulds J, Veldheer S. Commentary on Etter \& Bullen (2011): could ecigs become the ultimate nicotine maintenance device? Addiction (2011) 106:2029-30. doi:10.1111/j.1360-0443.2011.03532.x

14. Family Smoking Prevention and Tobacco Control and Federal Retirement Reform Act of 2009, Pub L No 111-31, 113 Stat 1776 (2009). Available from: http://www.gpo.gov/fdsys/pkg/PLAW-111publ31/pdf/PLAW-111publ31.pdf

15. Council on Science and Public Health (CSAPH), American Medical Association. Use of electronic cigarettes in smoking cessation programs. Report 6 (A10), 159th Annual Meeting. Chicago, IL: American Medical Association House of Delegates. Available from: http://www.ama-assn.org//resources/doc/csaph/ a10csaph6ft.pdf

16. Piano MR, Benowitz NL, Fitzgerald GA, Corbridge S, Heath J, Hahn E, et al. Impact of smokeless tobacco products on cardiovascular disease: implications for policy, prevention, and treatment: a policy statement from the American Heart Association. Circulation (2010) 122:1520-44. doi:10.1161/CIR. 0b013e3181f432c3

17. Avdalovic MV, Murin S. Electronic cigarettes: no such thing as a free lunch...Or puff. Chest (2012) 141:1371-2. doi:10.1378/chest.12-0205

18. Regan AK, Promoff G, Dube SR, Arrazola R. Electronic nicotine delivery systems: adult use and awareness of the 'e-cigarette' in the USA. Tob Control (2013) 22:19-23. doi:10.1136/tobaccocontrol-2011-050044

19. Kralikova E, Kubatova S, Truneckova K, Kmetova A, Hajek P. The electronic cigarette: what proportion of smokers have tried it and how many use it regularly? Addiction (2012) 107:1528-9. doi:10.1111/j.1360-0443.2012.03916.x

20. Kralikova E, Novak J, West O, Kmetova A, Hajek P. Do e-cigarettes have the potential to compete with conventional cigarettes? A survey of conventional cigarette smokers' experiences with e-cigarettes. Chest (2013) 144:1609-14. doi:10.1378/chest.12-2842 
21. Etter JF. Electronic cigarettes: a survey of users. BMC Public Health (2010) 10:231. doi:10.1186/1471-2458-10-231

22. Etter JF, Bullen C. Electronic cigarette: users profile, utilization, satisfaction and perceived efficacy. Addiction (2011) 106:2017-28. doi:10.1111/j.1360-0443. 2011.03505.x

23. Dawkins L, Turner J, Roberts A, Soar K. 'Vaping' profiles and preferences: an online survey of electronic cigarette users. Addiction (2013) 108:1115-25. doi:10.1111/add.12150

24. Dockrell M, Morrison R, Bauld L, McNeill A. E-cigarettes: prevalence and attitudes in great britain. Nicotine Tob Res (2013) 15:1737-44. doi:10.1093/ntr/ ntt057

25. Farsalinos KE, Romagna G, Tsiapras D, Kyrzopoulos S, Voudris V. Evaluating nicotine levels selection and patterns of electronic cigarette use in a group of "vapers" who had achieved complete substitution of smoking. Subst Abuse (2013) 7:139-46. doi:10.4137/SART.S12756

26. Barbeau AM, Burda J, Siegel M. Perceived efficacy of e-cigarettes versus nicotine replacement therapy among successful e-cigarette users: a qualitative approach. Addict Sci Clin Pract (2013) 8:5. doi:10.1186/1940-0640-8-5

27. Goniewicz ML, Lingas EO, Hajek P. Patterns of electronic cigarette use and user beliefs about their safety and benefits: an Internet survey. Drug Alcohol Rev (2013) 32:133-40. doi:10.1111/j.1465-3362.2012.00512.x

28. Polosa R, Caponnetto P, Morjaria JB, Papale G, Campagna D, Russo C. Effect of an electronic nicotine delivery device (e-cigarette) on smoking reduction and cessation: a prospective 6-month pilot study. BMC Public Health (2011) 11:786. doi:10.1186/1471-2458-11-786

29. Polosa R, Morjaria JB, Caponnetto P, Campagna D, Russo C, Alamo A, et al. Effectiveness and tolerability of electronic cigarette in real-life: a 24month prospective observational study. Intern Emerg Med (2013). doi:10.1007/ s11739-013-0977-z

30. Caponnetto P, Campagna D, Cibella F, Morjaria JB, Caruso M, Russo C, et al. EffiCiency and Safety of an eLectronic cigAreTte (ECLAT) as tobacco cigarettes substitute: a prospective 12-month randomized control design study. PLoS One (2013) 8:e66317. doi:10.1371/journal.pone.0066317

31. Caponnetto P, Auditore R, Russo C, Cappello GC, Polosa R. Impact of an electronic cigarette on smoking reduction and cessation in schizophrenic smokers: a prospective 12-month pilot study. Int J Environ Res Public Health (2013) 10:446-61. doi:10.3390/ijerph10020446

32. Vickerman KA, Carpenter KM, Altman T, Nash CM, Zbikowski SM. Use of electronic cigarettes among state tobacco cessation quitline callers. Nicotine Tob Res (2013) 15:1787-91. doi:10.1093/ntr/ntt061

33. Hua M, Alfi M, Talbot P. Health-related effects reported by electronic cigarette users in online forums. J Med Internet Res (2013) 15:e59. doi:10.2196/jmir.2324

34. Pokhrel P, Fagan P, Little MA, Kawamoto CT, Herzog TA. Smokers who try e-cigarettes to quit smoking: findings from a multiethnic study in Hawaii. Am J Public Health (2013) 103:e57-62. doi:10.2105/AJPH.2013.301453

35. Sutfin EL, McCoy TP, Morrell HE, Hoeppner BB, Wolfson M. Electronic cigarette use by college students. Drug Alcohol Depend (2013) 131:214-21. doi:10.1016/j.drugalcdep.2013.05.001

36. Cho JH, Shin E, Moon SS. Electronic-cigarette smoking experience among adolescents. J Adolesc Health (2011) 49:542-6. doi:10.1016/j.jadohealth.2011. 08.001

37. Pepper JK, Reiter PL, McRee AL, Cameron LD, Gilkey MB, Brewer NT. Adolescent males' awareness of and willingness to try electronic cigarettes. J Adolesc Health (2013) 52:144-50. doi:10.1016/j.jadohealth.2012.09.014

38. Choi K, Fabian L, Mottey N, Corbett A, Forster J. Young adults' favorable perceptions of snus, dissolvable tobacco products, and electronic cigarettes: findings from a focus group study. Am J Public Health (2012) 102:2088-93. doi:10.2105/AJPH.2011.300525

39. Choi K, Forster J. Characteristics associated with awareness, perceptions, and use of electronic nicotine delivery systems among young US Midwestern adults. Am J Public Health (2013) 103:556-61. doi:10.2105/AJPH. 2012.300947

40. Goniewicz ML, Zielinska-Danch W. Electronic cigarette use among teenagers and young adults in Poland. Pediatrics (2012) 130:e879-85. doi:10.1542/peds. 2011-3448

41. Hughes JR, Shiffman S, Callas P, Zhang J. A meta-analysis of the efficacy of over-the-counter nicotine replacement. Tob Control (2003) 12:21-7. doi:10.1136/tc.12.1.21
42. Rennard SI, Glover ED, Leischow S, Daughton DM, Glover PN, Muramoto $\mathrm{M}$, et al. Efficacy of the nicotine inhaler in smoking reduction: a doubleblind, randomized trial. Nicotine Tob Res (2006) 8:555-64. doi:10.1080/ 14622200600789916

43. Stead LF, Perera R, Bullen C, Mant D, Hartmann-Boyce J, Cahill K, et al. Nicotine replacement therapy for smoking cessation. Cochrane Database Syst Rev (2012) 11:CD000146. doi:10.1002/14651858.CD000146.pub4

44. Hughes JR, Keely J, Naud S. Shape of the relapse curve and long-term abstinence among untreated smokers. Addiction (2004) 99:29-38. doi:10.1111/j. 1360-0443.2004.00540.x

45. Siegel MB, Tanwar KL, Wood KS. Electronic cigarettes as a smoking-cessation tool: results from an online survey. Am J Prev Med (2011) 40:472-5. doi:10. 1016/j.amepre.2010.12.006

46. Bullen C, Howe C, Laugesen M, McRobbie H, Parag V, Williman J, et al. Electronic cigarettes for smoking cessation: a randomised controlled trial. Lancet (2013). doi:10.1016/S0140-6736(13)61842-5

47. Li J, Bullen C, Newcombe R, Walker N, Walton D. The use and acceptability of electronic cigarettes among New Zealand smokers. N Z Med J (2013) 126:48-57.

48. Cobb NK, Abrams DB. E-cigarette or drug-delivery device? Regulating novel nicotine products. N Engl J Med (2011) 365:193-5. doi:10.1056/ NEJMp1105249

49. Talhout R, Schulz T, Florek E, van Benthem J, Wester P, Opperhuizen A. Hazardous compounds in tobacco smoke. Int J Environ Res Public Health (2011) 8:613-28. doi:10.3390/ijerph8020613

50. Williams M, Villarreal A, Bozhilov K, Lin S, Talbot P. Metal and silicate particles including nanoparticles are present in electronic cigarette cartomizer fluid and aerosol. PLoS One (2013) 8:3. doi:10.1371/journal.pone.0057987

51. Stepanov I, Jensen J, Hatsukami D, Hecht SS. Tobacco-specific nitrosamines in new tobacco products. Nicotine Tob Res (2006) 8:309-13. doi:10.1080/ 14622200500490151

52. Goniewicz ML, Kuma T, Gawron M, Knysak J, Kosmider L. Nicotine levels in electronic cigarettes. Nicotine Tob Res (2013) 15:158-66. doi:10.1093/ntr/ nts 103

53. Goniewicz ML, Knysak J, Gawron M, Kosmider L, Sobczak A, Kurek J, et al. Levels of selected carcinogens and toxicants in vapour from electronic cigarettes. Tob Control (2013). doi:10.1136/tobaccocontrol-2012-050859

54. Schripp T, Markewitz D, Thornley S, Glover M, Laugesen M. Does ecigarette consumption cause passive vaping? Indoor Air (2013) 23:25-31. doi:10.1111/j.1600-0668.2012.00792.x

55. Kim HJ, Shin HS. Determination of tobacco-specific nitrosamines in replacement liquids of electronic cigarettes by liquid chromatography-tandem mass spectrometry. J Chromatogr A (2013) 1291:48-55. doi:10.1016/j.chroma.2013. 03.035

56. Pellegrino RM, Tinghino B, Mangiaracina G, Marani A, Vitali M, Protano C, et al. Electronic cigarettes: an evaluation of exposure to chemicals and fine particulate matter (PM). Ann Ig (2012) 24:279-88.

57. Hadwiger ME, Trehy ML, Ye W, Moore T, Allgire J, Westenberger B. Identification of amino-tadalafil and rimonabant in electronic cigarette products using high pressure liquid chromatography with diode array and tandem mass spectrometric detection. J Chromatogr A (2010) 1217:7547-55. doi:10.1016/j.chroma.2010.10.018

58. Moorea TW, Allgirea JF, Woodruffa JT, Ahadia SS, Blacka JC, Westenberger BJ. Analysis of electronic cigarette Cartridges, refill solutions and smoke from nicotine and nicotine related impurities. J Liq Chromatogr Relat Technol (2011) 34:1442-58. doi:10.1080/10826076.2011.572213

59. Bullen C, McRobbie H, Thornley S, Glover M, Laugesen M. Effect of an electronic nicotine delivery device (e cigarette) on desire to smoke and withdrawal, user preferences and nicotine delivery: randomised cross-over trial. Tob Control (2010) 19:98-103. doi:10.1136/tc.2009.031567

60. Cheah NP, Chong NW, Tan J, Morsed FA, Yee SK. Electronic nicotine delivery systems: regulatory and safety challenges: Singapore perspective. Tob Control (2012). doi:10.1136/tobaccocontrol-2012-050483

61. Flouris $\mathrm{AD}$, Oikonomou DN. Electronic cigarettes: miracle or menace? BMJ (2010) 340:c311. doi:10.1136/bmj.c311

62. Cameron JM, Howell DN, White JR, Andrenyak DM, Layton ME, Roll JM. Variable and potentially fatal amounts of nicotine in e-cigarette nicotine solutions. Tob Control (2013). doi:10.1136/tobaccocontrol-2012-050604 
63. Etter JF, Zäther E, Svensson S. Analysis of refill liquids for electronic cigarettes. Addiction (2013) 108:1671-9. doi:10.1111/add.12235

64. Chu VL. Nicotine replacement therapy for tobacco use cessation: reference table. J Pharm Pract (2006) 19:297-300. doi:10.1177/0897190007300456

65. Trtchounian A, Talbot P. Electronic nicotine delivery systems: is there a need for regulation? Tob Control (2011) 20:47-52. doi:10.1136/tc.2010.037259

66. Eissenberg T. Electronic nicotine delivery devices: ineffective nicotine delivery and craving suppression after acute administration. Tob Control (2010) 19:87-8. doi:10.1136/tc.2009.033498

67. Vansickel AR, Cobb CO, Weaver MF, Eissenberg TE. A clinical laboratory model for evaluating the acute effects of electronic "cigarettes": nicotine delivery profile and cardiovascular and subjective effects. Cancer Epidemiol Biomarkers Prev (2010) 19:1945-53. doi:10.1158/1055-9965.EPI-10-0288

68. Hughes JR, Goldstein MG, Hurt RD, Shiffman S. Recent advances in the pharmacotherapy of smoking. JAMA (1999) 281:72-6. doi:10.1001/jama.281.1.72

69. Anczak JD, Nogler RA II. Tobacco cessation in primary care: maximizing intervention strategies. Clin Med Res (2003) 1:201-16. doi:10.3121/cmr.1.3.201

70. Lunell E, Molander L, Ekberg K, Wahren J. Site of nicotine absorption from a vapour inhaler - comparison with cigarette smoking. Eur J Clin Pharmacol (2000) 55:737-41. doi:10.1007/s002280050007

71. Foulds J, Burke M, Steinberg M, Williams JM, Ziedonis DM. Advances in pharmacotherapy for tobacco dependence. Expert Opin Emerg Drugs (2004) 9:39-53. doi:10.1517/14728214.9.1.39

72. Sahu SK, Tiwari M, Bhangare RC, Pandit GG. Particle size distributions of mainstream and exhaled cigarette smoke and predictive deposition in human respiratory tract. Aerosol Air Qual Res (2013) 13:324-32.

73. Zhang Y, Sumner W, Chen DR. In vitro particle size distributions in electronic and conventional cigarette aerosols suggest comparable deposition patterns. Nicotine Tob Res (2012) 15:501-8. doi:10.1093/ntr/nts165

74. Ingebrethsen BJ, Cole SK, Alderman SL. Electronic cigarette aerosol particle size distribution measurements. Inhal Toxicol (2012) 24:976-84. doi:10.3109/ 08958378.2012.744781

75. Vansickel AR, Eissenberg T. Electronic cigarettes: effective nicotine delivery after acute administration. Nicotine Tob Res (2013) 15:267-70. doi:10.1093/ $\mathrm{ntr} / \mathrm{ntr} 316$

76. Dawkins L, Corcoran O. Acute electronic cigarette use: nicotine delivery and subjective effects in regular users. Psychopharmacology (Berl) (2013). doi:10.1007/s00213-013-3249-8

77. Vansickel AR, Weaver MF, Eissenberg T. Clinical laboratory assessment of the abuse liability of an electronic cigarette. Addiction (2012) 107:1493-500. doi:10.1111/j.1360-0443.2012.03791.x

78. Etter JF, Bullen C. Saliva cotinine levels in users of electronic cigarettes. Eur Respir J (2011) 38:1219-20. doi:10.1183/09031936.00066011

79. Flouris AD, Chorti MS, Poulianiti KP, Jamurtas AZ, Kostikas K, Tzatzarakis $\mathrm{MN}$, et al. Acute impact of active and passive electronic cigarette smoking on serum cotinine and lung function. Inhal Toxicol (2013) 25:91-101. doi:10.3109/08958378.2012.758197

80. Benowitz NL, Hansson A, Jacob P III. Cardiovascular effects of nasal and transdermal nicotine and cigarette smoking. Hypertension (2002) 39:1107-12. doi:10.1161/01.HYP.0000018825.76673.EA

81. Najem B, Houssière A, Pathak A, Janssen C, Lemogoum D, Xhaët O, et al. Acute cardiovascular and sympathetic effects of nicotine replacement therapy. Hypertension (2006) 47:1162-7. doi:10.1161/01.HYP.0000219284.47970.34

82. Czogala J, Cholewinski M, Kutek A, Zielinska-Danch W. Evaluation of changes in hemodynamic parameters after the use of electronic nicotine delivery systems among regular cigarette smokers. Przegl Lek (2012) 69:841-5.

83. Farsalinos KE, Romagna G, Tsiapras D, Kyrzopoulos S, Voudris V. Evaluation of electronic cigarette use (vaping) topography and estimation of liquid consumption: implications for research protocol standards definition and for public health authorities' regulation. Int J Environ Res Public Health (2013) 10:2500-14. doi:10.3390/ijerph10062500

84. Trtchounian A, Williams M, Talbot P. Conventional and electronic cigarettes (e-cigarettes) have different smoking characteristics. Nicotine Tob Res (2010) 12:905-12. doi:10.1093/ntr/ntq114

85. Hua M, Yip H, Talbot P. Mining data on usage of electronic nicotine delivery systems (ENDS) from YouTube videos. J Med Internet Res (2013) 15:e59. doi:10.1136/tobaccocontrol-2011-050226
86. Williams M, Talbot P. Variability among electronic cigarettes in the pressure drop, airflow rate, and aerosol production. Nicotine Tob Res (2011) 13:1276-83. doi:10.1093/ntr/ntr164

87. Sherwood N. Effects of nicotine on human pschomotor performance. Hum Psychopharmacol (1993) 8:155-84. doi:10.1002/hup.470080302

88. Heishman SJ, Kleykamp BA, Singleton EG. Meta-analysis of the acute effects of nicotine and smoking on human performance. Psychopharmacology (Berl) (2010) 210:453-69. doi:10.1007/s00213-010-1848-1

89. Baron JA. Beneficial effects of nicotine and cigarette smoking: the real, the possible and the spurious. Br Med Bull (1996) 52:58-73. doi:10.1093/ oxfordjournals.bmb.a011533

90. Dawkins L, Turner J, Crowe E. Nicotine derived from the electronic cigarette improves time-based prospective memory in abstinent smokers. Psychopharmacology (Berl) (2013) 227:377-84. doi:10.1007/s00213-013-2983-2

91. Dawkins L, Turner J, Hasna S, Soar K. The electronic-cigarette: effects on desire to smoke, withdrawal symptoms and cognition. Addict Behav (2012) 37:970-3. doi:10.1016/j.addbeh.2012.03.004

92. Evans DE, Drobes DJ. Nicotine self-medication of cognitive-attentional processing. Addict Bio (2009) 14:32-42. doi:10.1111/j.1369-1600.2008.00130.x

93. Laviolette SR, van der Kooy D. The neurobiology of nicotine addiction: bridging the gap from molecules to behaviour. Nat Rev Neurosci (2004) 5:55-65. doi: $10.1038 / \mathrm{nrn} 1298$

94. Lewis A, Miller JH, Lea RA. Monoamine oxidase and tobacco dependence. Neurotoxicology (2007) 28:182-95. doi:10.1016/j.neuro.2006.05.019

95. Fowler JS, Volkow ND, Wang GJ, Pappas N, Logan J, Shea C, et al. Brain monoamine oxidase A inhibition in cigarette smokers. Proc Natl Acad Sci U S A (1996) 93:14065-9. doi:10.1073/pnas.93.24.14065

96. Fowler JS, Volkow ND, Wang GJ, Pappas N, Logan J, MacGregor R, et al. Inhibition of monoamine oxidase B in the brains of smokers. Nature (1996) 379:733-6. doi:10.1038/379733a0

97. Casella G, Caponnetto P, Polosa R. Therapeutic advances in the treatment of nicotine addiction: present and future. Ther Adv Chronic Dis (2010) 1:95-106. doi:10.1177/2040622310374896

98. Gross J, Stitzer ML. Nicotine replacement: ten-week effects on tobacco withdrawal symptoms. Psychopharmacology (Berl) (1989) 98:334-41. doi:10.1007/ BF00451684

99. McCauley L, Markin C, Hosmer D. An unexpected consequence of electronic cigarette use. Chest (2012) 141:1110-3. doi:10.1378/chest.11-1334

100. Vardavas CI, Anagnostopoulos N, Kougias M, Evangelopoulou V, Connolly GN, Behrakis PK. Short-term pulmonary effects of using an electronic cigarette: impact on respiratory flow resistance, impedance, and exhaled nitric oxide. Chest (2012) 141:1400-6. doi:10.1378/chest.11-2443

101. Hansson L, Choudry NB, Karlsson JA, Fuller RW. Inhaled nicotine in humans: effect on the respiratory and cardiovascular systems. J Appl Physiol (1994) 76:2420-7.

102. Smith AD, Taylor DR. Is exhaled nitric oxide measurement a useful clinical test in asthma? Curr Opin Allergy Clin Immunol (2005) 5:49-56. doi:10.1097/ 00130832-200502000-00010

103. Jatakanon A, Lim S, Kharitonov SA, Chung KF, Barnes PJ. Correlation between exhaled nitric oxide, sputum eosinophils, and methacholine responsiveness in patients with mild asthma. Thorax (1998) 53:91-5. doi:10.1136/thx.53.2.91

104. Taylor DR, Pijnenburg MW, Smith AD, de Jongste JC. Exhaled nitric oxide measurements: clinical application and interpretation. Thorax (2006) 61:817-27. doi:10.1136/thx.2005.056093

105. Taylor DR, Mandhane P, Greene JM, Hancox RJ, Filsell S, McLachlan CR, et al. Factors affecting exhaled nitric oxide measurements: the effect of sex. Respir Res (2007) 8:82. doi:10.1186/1465-9921-8-82

106. Karrasch S, Ernst K, Behr J, Heinrich J, Huber RM, Nowak D, et al. Exhaled nitric oxide and influencing factors in a random population sample. Respir Med (2011) 105:713-8. doi:10.1016/j.rmed.2010.11.002

107. Malinovschi A, Janson C, Holmkvist T, Norback D, Merilainen P, Hogman M. Effect of smoking on exhaled nitric oxide and flow-independent nitric oxide exchange parameters. Eur Respir J (2006) 28:339-45. doi:10.1183/09031936. 06.00113705

108. Habib SS, Ahmed SM, Al Drees AM, Husain A. Effect of cigarette smoking on fractional exhaled nitric oxide in Saudi medical college students. J Pak Med Assoc (2011) 61:120-3. 
109. Yoda Y, Otani N, Hasunuma H, Kanegae H, Shima M. Storage conditions for stability of offline measurement of fractional exhaled nitric oxide after collection for epidemiologic research. BMC Pulm Med (2012) 12:68. doi:10.1186/1471-2466-12-68

110. Robbins RA, Millatmal T, Lassi K, Rennard S, Daughton D. Smoking cessation is associated with an increase in exhaled nitric oxide. Chest (1997) 112:313-8. doi:10.1378/chest.112.2.313

111. McMillan K, Bredt DS, Hirsch DJ, Snyder SH, Clark JE, Masters BS. Cloned, expressed rat cerebellar nitric oxide synthase contains stoichiometric amounts of heme, which binds carbon monoxide. Proc Natl Acad Sci U S A (1992) 89:11141-5. doi:10.1073/pnas.89.23.11141

112. Johnson FK, Johnson RA. Carbon monoxide promotes endotheliumdependent constriction of isolated gracilis muscle arterioles. Am J Physiol Regul Integr Comp Physiol (2003) 285:R536-41.

113. Caponnetto P, Polosa R, Russo C, Leotta C, Campagna D. Successful smoking cessation with electronic cigarettes in smokers with a documented history of recurring relapses: a case series. J Med Case Reports (2011) 5:585-90. doi:10.1186/1752-1947-5-585

114. Chambers DC, Tunnicliffe WS, Ayres JG. Acute inhalation of cigarette smoke increases lower respiratory tract nitric oxide concentrations. Thorax (1998) 53:677-9. doi:10.1136/thx.53.8.677

115. Buda K, Kulinska K, Billert H. Acute smoking effect in respect to exhaled nitric oxide - a preliminary report. Przegl Lek (2011) 68:738-41.

116. Wieslander G, Norback D, Lindgren T. Experimental exposure to propylene glycol mist in aviation emergency training: acute ocular and respiratory effects. Occup Environ Med (2001) 58:649-55. doi:10.1136/oem.58.10.649

117. Choi H, Schmidbauer N, Sundell J, Hasselgren M, Spengler J, Bornehag C. Common household chemicals and the allergy risks in pre-school age children. PLoS One (2010) 5:e13423. doi:10.1371/journal.pone.0013423

118. Robertson OH, Loosli CG, Puck TT, Wise H, Lemon HM, Lester W. Tests for the chronic toxicity of propylene glycol and triethylene glycol on monkeys and rats by vapor inhalation and oral administration. J Pharmacol Exp Ther (1947) 91:52-76.

119. Bahl V, Lin S, Xu N, Davis B, Wang YH, Talbot P. Comparison of electronic cigarette refill fluid cytotoxicity using embryonic and adult models. Reprod Toxicol (2012) 34:529-37. doi:10.1016/j.reprotox.2012.08.001
120. Romagna G, Allifranchini E, Bocchietto E, Todeschi S, Esposito M, Farsalinos KE. Cytotoxicity evaluation of electronic cigarette vapor extract on cultured mammalian fibroblasts (ClearStream-LIFE): comparison with tobacco cigarette smoke extract. Inhal Toxicol (2013) 25:354-61. doi:10.3109/08958378. 2013.793439

121. Flouris AD, Poulianiti KP, Chorti AZ, Jamurtas MS, Kouretas D, Owolabi EO, et al. Acute effects of electronic and tobacco cigarette smoking on complete blood count. Food Chem Toxicol (2012) 50:3600-3. doi:10.1016/j.fct.2012.07. 025

122. Bridges AB, Hill A, Belch JJ. Cigarette smoking increases white blood cell aggregation in whole blood. JR Soc Med (1993) 86:139-40.

123. Farsalinos KE, Romagna G. Chronic idiopathic neutrophilia in a smoker, relieved after smoking cessation with the use of electronic cigarette a case report. Clin Med Insights Case Rep (2013) 6:15-21. doi:10.4137/CCRep. S11175

124. Noel J, Rees VW, Connolly GN. Electronic cigarettes: a new 'tobacco’ industry? Tob Control (2011) 20:81. doi:10.1136/tc.2010.038562

Conflict of Interest Statement: The author declares that the research was conducted in the absence of any commercial or financial relationships that could be construed as a potential conflict of interest.

Received: 09 August 2013; accepted: 01 November 2013; published online: 18 November 2013.

Citation: Palazzolo DL (2013) Electronic cigarettes and vaping: a new challenge in clinical medicine and public health. A literature review. Front. Public Health 1:56. doi: 10.3389/fpubh.2013.00056

This article was submitted to Public Health Education and Promotion, a section of the journal Frontiers in Public Health.

Copyright (c) 2013 Palazzolo. This is an open-access article distributed under the terms of the Creative Commons Attribution License (CC BY). The use, distribution or reproduction in other forums is permitted, provided the original author(s) or licensor are credited and that the original publication in this journal is cited, in accordance with accepted academic practice. No use, distribution or reproduction is permitted which does not comply with these terms. 